\title{
Measuring public value: scale development and construct validation
}

\section{Timo Meynhardt \& Anna Jasinenko}

To cite this article: Timo Meynhardt \& Anna Jasinenko (2020): Measuring public value: scale development and construct validation, International Public Management Journal, DOI: 10.1080/10967494.2020.1829763

To link to this article: https://doi.org/10.1080/10967494.2020.1829763

\section{+ View supplementary material $₫$}

\section{曲 Published online: 29 Oct 2020.}

Submit your article to this journal $\pi$

III Article views: 33

Q View related articles ¿

View Crossmark data $₫$ 


\title{
Measuring public value: scale development and construct validation
}

\author{
Timo Meynhardt ${ }^{a, b}$ (D) and Anna Jasinenko ${ }^{a, c}$ (D) \\ ${ }^{a}$ HHL Leipzig Graduate School of Management; ${ }^{b}$ University of St. Gallen; ${ }^{C}$ University of Lausanne
}

\begin{abstract}
The public value concept is highly popular among practitioners and researchers, yet, to further test and develop the construct it needs more diversity in empirical research. We aim to contribute to future empirical public value research by providing a new public value scale based on Meynhardt's conceptualization of public value. Conducting two empirical surveys with highly representative samples, we have developed and validated a twelve-item public value scale. Additionally, we applied the scale to empirically test what distinguishes public value from adjacent constructs, such as CSR or reputation, and to examine its explanatory power regarding important client/customer outcomes. The scale will allow future research to test extant public value hypotheses more thoroughly than before by using survey or experimental research designs. Practitioners can use the scale to gain a deeper understanding of public evaluation.
\end{abstract}

\section{ARTICLE HISTORY}

Received 16 November 2019

Accepted 24 September 2020

Public value has become, in the last few decades, a popular framework in practice and research. Specifically, UK, US, and Australian public organizations have come to appreciate this concept (e.g., Podger 2017; Rhodes and Wanna 2007; Wallmeier, Helmig, and Feeney 2019). Bryson, Crosby, and Bloomberg $(2014,445)$ suggest that public value governance is a highly needed "response to the challenges of a networked, multi-sector, no-one-wholly in-charge world and to the shortcomings of previous public administration approaches." However, scholars argue that public value creation is not limited to public organizations, but that private organizations (forprofit or non-profit) also contribute to the common good and thus create public value (Meynhardt 2015; Moulton 2009). Especially currently, with global financial crises and various corporate scandals questioning the legitimacy of many private organizations, public value seems to offer an interesting approach also for private organizations to coordinate through times of shrinking trust and support (Meynhardt 2015).

Despite the great popularity and importance of public value, the concept is still contested (Hartley et al. 2017; Williams and Shearer 2011). Among other issues, how it is specifically conceptualized, how distinguished from other related concepts, and what success it delivers, remain in question. One possible reason for this contestation is the relative scarcity of diverse empirical research in the public value domain (Bryson et al. 2014; Hartley et al. 2017; Meynhardt and Bartholomes 2011; Williams and Shearer 2011). Specifically, Hartley et al. (2017) criticism is that, to date, empirical public value research predominantly used case study designs and focused on managerial perspectives of public value creation (e.g., Bozeman and Feeney 2007; Bozeman and Sarewitz 2011; Moulton and Feeney 2011). Although this line of research certainly contributed to 
an elaborate understanding of various important public value creation fields (e.g., health systems, science policies, public mortgage programs), the findings are highly context-specific and, therefore, not generalizable to other fields. Moreover, a manager-centered approach neglects perspectives of other stakeholders that are at least equally important. Additional empirical research methods such as surveys, interviews, or experiments, as well as other perspectives such as those of citizens, business partners, and clients, could be helpful in further developing, testing, and challenging the current public value conceptualization (Bryson et al. 2014; Hartley et al. 2017).

This article aims to address the above-mentioned shortcomings by developing and validating a public value scale that focuses on citizens' perspectives and enables quantitative survey research. It contributes to the field in three ways: First, the main contribution is a validated public value scale that focuses on public perceptions and establishes a basis for future quantitative public value research. Second, we add to the theoretical public value discourse that questions public value as a distinct construct (Meynhardt and Bartholomes 2011). We empirically investigate and theoretically discuss public value's distinctive properties that differentiate between it and adjacent concepts, such as reputation and corporate social responsibility (CSR). Third, we contribute to the public value discourse by empirically testing the contested effectiveness ascribed to public value (Williams and Shearer 2011). We test the explanatory power of public value on diverse client/customer attitudes and behaviors that give a first insight, how individuals react to organizational public value. Overall, the developed public value scale enables the measuring, and consequently the testing of Meynhardt's public value construct in various contexts. Thereby it can support scholars, as well as practitioners, in quantifying an organization's public value. Thus, it can become a basis for informed decisions and future strategies.

\section{Public value}

Public value is broadly defined as an abstract entity "producing what is either valued by the public, is good for the public, or both" (Bryson et al. 2014, 448). Since Moore (1995) coined the term public value in his seminal work "Creating Public Value," the concept became highly popular among practitioners and scholars (Hartley et al. 2017; Williams and Shearer 2011). In the following two decades, much conceptual, theoretical, and scholarly work was done on the public value concept, which resulted in a broad theoretical foundation with many interesting arguments, but also in vast complexity and ambiguity. To illustrate, besides Moore's initial approach, Bryson et al. (2014) identified Bozeman's (2007) idea of public values based on societal consensus, Benington's (2011) definition of public value creation as a contested democratic practice that adds to the public sphere, and Meynhardt's (2009) psychological public value approach based on basic need fulfillment, as the "major contributions to public value literature" (Bryson et al. 2014, 448; see also Bryson et al. 2017; Hartley et al. 2019). Overall, these four leading public value conceptualizations agree on the importance of thinking beyond an economic or financial level in creating public value. Even though Moore (1995) initially focused on public managers' tasks in creating public value, most of the recent public value scholars agree that we need a more holistic perspective. Bozeman (2007), Benington (2011), and Meynhardt (2009) all focus primarily on public value's embeddedness in society.

These scholars criticize the prior perception of the public as passive recipients, suggesting that public value is not simply produced, but is co-created within its ecosystems. A great deal of ambiguity in the different conceptualizations lies in actually identifying public value and in the various theoretical foundations' foci. This ambiguity prompts a fundamental question on what public value exactly is. The complexity of possible answers to this question seems to hamper empirical research (Hartley et al. 2017; Williams and Shearer 2011). Accordingly, Hartley et al. (2017, 673) advise that the different conceptualizations "should not act as a brake on empirical research as 
long as scholars are clear and explicit about their definition of the concepts." this article focuses on Meynhardt's $(2009,2015)$ public value conceptualization that we define in more detail below.

\section{Meynhardt's public value approach}

According to Meynhardt $(2009,205)$ "public value is anything people put value to with regard to the public." More specifically, he defines public value creation as "situated in relationships between the individual and society, founded in individuals, constituted by subjective evaluations against basic needs, activated by and realized in emotional-motivational states, and produced and reproduced in experience-intense practices" (Meynhardt 2009, 212). We suggest Meynhardt's $(2009,2015)$ public value conceptualization for developing a scale because (1) it provides subjectively based micro-foundations of public value that are, however, (2) theoretically connected to the macro-level (i.e., the public level), and are moreover, (3) structured in four psychologically based dimensions. These three attributes of Meynhardt's public value conceptualization, overall, provide theoretically sound and practically feasible prerequisites of developing a public value scale.

\section{Subjective micro-foundations}

Meynhardt's (2009) builds on Heyde's (1926) relational value understanding that reflects the "notion of value as a result of a relationship between a subject that is valuing an object and the valued object" (Meynhardt 2009, 198). Consequently, each public value evaluation is subjective and bound to each individuals' subjective relation to the object of evaluation. Accordingly, public value cannot simply be delivered by a manager or organization, but needs to be subjectively valued by the public that, in turn, is made up of individuals. Only if we understand how individuals subjectively perceive organizations' public value, can we estimate an overall public value. Put differently, "[c]reating is not just about delivering, but also about recognition and perception" (Meynhardt and Bartholomes 2011, 289). This focus on individual subjective evaluation of value provides micro-foundations (Meynhardt 2015) that are a prerequisite to quantitative scale development.

\section{Synergetic interplay between the micro and macro-level}

Notably, it is not enough to understand public value as a simple summation of individual selfinterests (Meynhardt 2009). Hence, Meynhardt $(2015,149)$ proposes that "[p]ublic value as a collectively shared value is not constructed as a sum of individual values, but their common and overlapping meaning about the quality of a relationship involving the public." Synergetic value co-creation results from the constant dynamic interplay between individuals and the public (Meynhardt, Chandler, and Strathoff 2016). This line of thinking conceptualizes public value as a synergetic order parameter emerging from interactions at the micro-level (Meynhardt et al. 2016). As such, public value is a macro-level phenomenon, which connects the individual with a social entity, such as the family, community, or society at large (Meynhardt and Fröhlich 2019). Meynhardt $(2015,152)$ defines the public as a "constantly (re)negotiated, tested, or invented operational fiction" (Meynhardt 2015, 152) that serves as an important point of reference for evaluation. In this line of thinking, the public is an indispensable "operational fiction" (Meynhardt 2009, 204)-necessary for action and orientation in a complex environment. This characteristic of the otherwise highly subjective public value concept is especially valuable to an empirical operationalization because it acknowledges its complexity, while offering a feasible approximation of collectively shared values. Practically, this means that public value is not determined by an egoistic value perception (i.e., what individuals perceive as valuable to themselves), but by individual perceptions of value for the public, which in that way is also valuable to the individual. In other words, one way or another, the value individuals attach to the public good is functionally important for fulfilling individual's needs (Meynhardt 2015). 
Table 1. Public value dimensions, content, and item examples (based on Meynhardt 2009, 2015).

\begin{tabular}{|c|c|c|}
\hline Public value dimension & Content & $\begin{array}{l}\text { Item examples: } \\
\text { The organization ... }\end{array}$ \\
\hline moral-ethical & $\begin{array}{l}\text { - Based on need for self-worth } \\
\text { and dignity } \\
\text { - Related to subjective moral and } \\
\text { ethical standards of how humans } \\
\text { should be treated } \\
\text { - Striving for equality, } \\
\text { fairness, ethicality }\end{array}$ & $\begin{array}{l}\text { - behaves decently is fair } \\
\text { - } \text { acts ethically correct } \\
\text { - } \text { is just } \\
\text { respects the human dignity of } \\
\text { individuals }\end{array}$ \\
\hline hedonistic-aesthetical & $\begin{array}{l}\text { - Based on individuals' need and } \\
\text { motivation to avoid pain and } \\
\text { maximize pleasure } \\
\text { - Ranges from basic need to survive } \\
\text { to positive hedonistic experiences } \\
\text { - Strives for happiness, joy, } \\
\text { relaxation, beauty }\end{array}$ & $\begin{array}{l}\text { - contributes to the quality of life in } \\
\text { - } \text { is enitzerland } \\
\text { Switzerlandle for people in } \\
\text { - } \quad \text { is pleasant for people in } \\
\text { Switzerland } \\
\text { - contributes to the happiness of the } \\
\text { people in Switzerland } \\
\text { - contributes to the well-being of the } \\
\text { people in Switzerland }\end{array}$ \\
\hline utilitarian-instrumental & $\begin{array}{l}\text { - Based on need to understand, } \\
\text { predict and control environment } \\
\text { - Strives for utility, efficiency, and } \\
\text { effectivity } \\
\text { - Also encompasses subjectively } \\
\text { perceived financial or } \\
\text { economic value }\end{array}$ & $\begin{array}{l}\text { - performs well in its core business } \\
\text { - } \quad \text { is economically viable } \\
\text { - Switzerland } \\
\text { - } \quad \text { contributes to economic welfare in } \\
\text { Switzerland } \\
\text { - provides good quality to people in } \\
\text { Switzerland }\end{array}$ \\
\hline political-social & $\begin{array}{l}\text { - } \quad \text { Based on need for social } \\
\text { relatedness and belonging } \\
\text { - Strives for positive relationships, } \\
\text { social identity, or } \\
\text { group membership } \\
\text { - } \text { Ranges from belonging to } \\
\text { cooperation and solidarity }\end{array}$ & $\begin{array}{l}\text { - } \quad \text { contributes to social cohesion in } \\
\text { - } \text { creates a community in Switzerland } \\
\text { - has a positive effect on social } \\
\text { relationships in Switzerland } \\
\text { - } \text { contributes to solidarity in } \\
\text { Switzerland } \\
\text { - contributes to cooperation in } \\
\text { Switzerland }\end{array}$ \\
\hline
\end{tabular}

\section{Four-dimensional structure of public value}

To better understand the psychological foundation of the social evaluation of value, Meynhardt (2009) proposes that evaluation is embedded in basic needs. "Needs concern deficits, i.e., felt discrepancies between an actual and desired psychological state that result in a motivation to act. Needs serve as actual or hypothetical reference points for evaluation; they function as the whats of the should" (Meynhardt 2009, 201). Accordingly, individuals' basic needs and their possible fulfillment, structure their public value evaluation, at least implicitly. If an individual subjectively evaluates organizational or managerial behavior to contribute to their subjective need fulfillment, they will evaluate it positively. Without such fulfillment, individuals feel psychological discomfort, which can destroy value, resulting in a negative individual evaluation. Based on Epstein's (2003) cognitive-experiential self-theory, which structures human basic needs into four main dimensions, Meynhardt (2009) postulates four public value dimensions: the moral-ethical, political-social, utilitarian-instrumental, and hedonistic-aesthetical dimension (see Table 1). Epstein (2003) suggests that independent of culture, gender, or age, all humans depend on these four basic needs at least to some degree and, hence, rely on them explicitly or implicitly as foundation in motivation and evaluation. Overall, with public value evaluations embedded in the four-dimensional structure of basic needs, we can approach the broad and complex field of public values comprehensively and in a structured way. Certainly, the four dimensions are not similarly explicit compared to the manifold public values found in prior research (e.g., Jorgensen and Bozeman 2007; Van Der Wal et al. 2006). However, the four-dimensional approach allows us to account for an exhaustive 
perspective independent of culture or other individual evaluator differences, whereas more explicit value formulations will most probably only partially reflect the public perspective due to the complexity resulting from consideration of all explicit values (Meynhardt 2009; Meynhardt, Jasinenko, et al. 2019).

\section{Public value scale development and validation}

Following Meynhardt's (2009, 2015) psychologically based public value conceptualization, we operationalize public value as the social evaluation against basic need fulfillment on the individual level, yet related to the public. Any social entity, such as a government, state, nation, community, or organization can be an object of public value evaluation. However, given this article's focus on organizational research, we limit our attention to public and private organizations. We argue that the public evaluates organizations independent of their sector, in reference to individual basic needs and accordingly based on the four public value dimensions (Meynhardt 2015). Especially nowadays, with public organizations focusing increasingly on effectiveness and concepts such as new public management on the one side, and private organizations indulging in concepts such as CSR on the other, the sectoral lines of values become blurred (Bozeman 1987; Van der Wal, De Graaf, and Lasthuizen 2008). Overall, all types of organizations depend on public legitimacy that, in the end, only comes with public value.

Using an empirical approach, first, we aim to validate the above outlined four-dimensional representation of an individual-based, second-order reflective, organizational public value construct. Second, we develop a parsimonious, yet multi-faceted survey scale based on this construct. Third, we use the scale we develop to validate the public value concept (as defined by Meynhardt 2009) by examining the construct's distinctiveness and its explanatory power. We developed the public value scale in a three-step approach. In the first step, we created an initial item pool and assessed its content adequacy. In the second step, using a survey, we tested the initial items empirically. In the third step, we re-tested and validated the best fitting items identified in step two on a larger sample, in a broader application field, and in comparison to adjacent measures.

\section{Step 1: initial item pool}

\section{Method}

We base the initial item pool's development on Meynhardt's $(2009,2015)$ public value definition and the fundamental work of Epstein's (2003) cognitive-experiential self-theory. Multiple in-class discussions and workshops with different groups of management graduate students over three years inspired the item formulation. Our goal in formulating the items was to find a range of representations for each public value dimension. Based on theory, needs build reference points for a public value assessment (Meynhardt 2009). Following this, individuals built their evaluations on subjectively experienced discrepancies between the actual state and an individual optimum. Consequently, it was especially important to find verbalizations that, on the one hand, are well known und easily understood, but on the other hand, leave room for subjective interpretation, which is essential for the subjectivity of Meynhardt's public value definition. We developed the items following the theoretical descriptions of each public value dimension.

\section{Moral-ethical dimension}

First, the moral-ethical public value dimension represents "a collectively shared value ascribed to personhood and what it means to be human" (Meynhardt 2015, 154). It builds on the basic human need for self-worth and dignity. Thus, individuals' moral and ethical standards embedded 
in and, therefore, influenced by society, are involved. In the organizational context, this dimension considers how an organization treats individuals or, more specifically, whether an organization respects and contributes to people's self-worth and dignity. Consequently, to contribute to public value in the moral-ethical dimension an organization has to show fair, just, ethically correct, or at least decent, behavior. As human dignity and self-worth relates equally to all humans, we formulate the items without specifying any community context (e.g., national context). A context-free formulation allows individuals implicitly or explicitly to choose an evaluation frame that they find most appropriate, to include thereby their own subjective perception of ethicality (Meynhardt and Fröhlich 2019).

\section{Hedonistic-aesthetic dimension}

Second, the hedonistic-aesthetic dimension represents "a collectively shared value ascribed to pleasure and what it means to create a positive experience" (Meynhardt 2015, 154). It originates from the evolutionarily deeply ingrained need to avoid pain and maximize pleasure in order to survive (Meynhardt 2015). Thus, this dimension refers to individuals' negative versus positive experiences embedded in and influenced by society. In the organizational context, this considers how organizations can contribute to positive experiences and maximize pleasure. Hence, an organization has to contribute to people's quality of life, making it pleasant or enjoyable. For this dimension, we formulated the items related to a national context (i.e., Switzerland) because we want, primarily, to activate the collectivity of this value by activating a public evaluation frame (Meynhardt and Fröhlich 2019), and second we intend to present a frame to which all participants could relate. We think that the national frame best fits this purpose because media and politics often discuss major issues on a national level and, for example, passports and national legislation give every resident at least some level of identification with a nation.

\section{Utilitarian-instrumental dimension}

Third, the utilitarian-instrumental dimension represents "a collectively shared value ascribed to utility and what it means to create a benefit efficiently." (Meynhardt 2015, 154). It builds on the basic need to have control and coherence in one's conceptual system (Meynhardt 2009, 2015), thus referring to people's ability to understand, predict, and control the environment (Meynhardt 2009). In the organizational context, that means organizations can create public value by providing reliable and effective services and products which help the society to better deal with its environment (e.g., by reducing excessive complexity). Consequently, organizations have to do a good job in their core business to create public value in this dimension. Moreover, they can support a society's stability and coherence by reliable financial performance. Thus, shareholder value or profitability can also contribute to public value, conditional on such financial performance also being subjectively publicly valued (Meynhardt 2009). Even if most citizens do not have detailed information on an organization's financial performance, they do have a sense of its economic well-being. Especially in times of crisis, it becomes evident that economic performance affects people's basic need for coherence and control. For example, the economic instability of banks during the recent financial crisis brought the stability and coherence of the whole system into question, and resulted widely in negative feelings that destroyed public value. Because it is often not transparent to the general public where financial profits are accounted for, especially those of multinational organizations, we do not formulate a context frame (e.g., nation) for the items that relate to financial aspects. However, we do formulate a national context frame for items that refer to the professionalism or quality of an organization, because such evaluations might vary according to national context. 


\section{Political-social dimension}

Fourth, the political-social dimension represents "a collectively shared value attached to social relationships and what it means to establish positive group relations" (Meynhardt 2015, 154). It is based on the basic need for social belonging (Meynhardt 2009), according to which individuals strive for positive relationships, social identity, or group membership (Meynhardt 2015). In an organizational context, that means organizations have to contribute to social cohesion, belonging, and overall to positive social relationships in order to create public value in this dimension. They could do so by either directly providing services or products that support social relationships and cooperation, or indirectly by providing access to everybody (e.g., offering affordable prices, assuring disabled-friendliness), or by supporting values of solidarity and cooperation within a society. But, similar to the other three public value dimensions, this value lies in the eye of the beholder. As for the hedonistic-aesthetic dimension, we formulated the items of the political-social within a national context frame (i.e., Switzerland). Again, we want thereby to activate the awareness of a public frame to which most participants can sufficiently relate (Meynhardt and Fröhlich 2019).

Based on these definitions of the public value dimensions we formulated a first item pool of nearly 100 items (i.e., 25 per dimension). Table 1 provides an overview of each dimension's content, as well as some exemplary items in this first item pool. Additionally, we asked four scholars that are familiar with Meynhardt's public value approach to review these initial 100 items regarding their content validity (meaning the extent to which they reflect the public value conceptualization and the intended dimensions). They also checked for redundancy and clarity, as well as for the grammatical and reading levels (as proposed by Worthington and Whittaker 2006).

\section{Analysis and results}

The public value scholars' expert review revealed that several items could apply to more than one dimension, lacked clarity, or were redundant. Hence, we deleted approximately half of the initial item pool, leaving us with 52 items, and still at least ten items per dimension (see an overview of all items in Table A1 in the appendix).

\section{Step 2: pre-study}

\section{Method}

To recruit our sample for the pre-study, we cooperated with the independent Swiss market research agency intervista (intervista.ch) that invited German speaking Swiss citizens to participate in our online survey in exchange for some bonus points (that could later be exchanged for vouchers). For our study, intervista randomly invited participants from their panel of more than 100,000 active members. The final sample consisted of 252 participants aged between 18 and 82 $(M=49.02, S D=17.01)$, of whom $54.4 \%$ were female. Only $28.2 \%$ of the participants had a higher education (i.e., college or university). This distribution of the demographic data is close to the distribution for the general Swiss population, indicating a sample highly representative of the general Swiss public.

We chose two organizations as objects of evaluation to validate the identified 52 items. Approximately half of the participants evaluated the public value of SRF $(N=129)$, a public Swiss TV and radio broadcasting organization. The other half evaluated Nestlé $(N=123)$, a private Swiss multinational food and drink processing organization. We chose these two organizations because they are highly familiar in Switzerland. A high familiarity of the evaluated company among the Swiss society is an important prerequisite of the method, because it assured that we relatively easily found participants who felt confident about evaluating the organization; this enabled us to find a sample representing the national demographics. Moreover, the two companies selected represent organizations with a wide range of features (e.g., public vs. private, 
national vs. international outreach). This was an initial approach to test the scale's hypothesized wide applicability. Specifically, it enabled us to test whether the anticipated four-dimensional structure and the item formulations would work for different types of organizations. Notably, our limited selection of two companies does not allow us to compare the public value results of private versus public organizations; it does, however, show that the method can be successfully used for the various organizational types.

The online questionnaire started with participants giving their demographic data, such as age, gender, and education. Next, they were introduced to one of the two organizations (randomly assigned) with its name and logo, and asked to indicate how familiar they were with the presented organization on a six-point Likert scale, ranging from 1 "not familiar at all" to 6 "very familiar." Only participants with at least a 4 on the familiarity scale could eventually rate the organization's public value, because participants had to be at least somewhat familiar with an organization they would evaluate. Next, these participants rated the presented organization using the 52 items (e.g., "[The organization] behaves decently") on a six-point Likert scale (1= "I do not agree" to $6=$ "I agree"). Since this study was the first check of the given items, we also included an additional "I don't know" option to gauge which items were too complicated or unclear.

\section{Analysis and results}

First, we analyzed the "I don't know" answers of all items for both organizational sub-samples. In sum, we found seven items that had high "I don't know" responses in both organizational cases $(\geq 11)$ and, hence, excluded them from the item pool. Next, we split the sample according to the evaluated organization. Using the sample that evaluated SRF $(N=129)$, we conducted a principal component analysis with the 45 remaining items, using Varimax with Kaiser Normalization as the rotation method to analyze the structure and to minimize the number of items. To identify the number of factors, we used, first, the highly popular scree plot analyses (Cattell 1966), which suggested a four-factor structure. Since scholars have criticized Cattell's scree plot analysis for being highly subjective, we additionally conducted a Velicer's (1976) minimum average partial (MAP) analysis (e.g., O'connor 2000). The MAP analysis also confirmed the four-factor structure. The four factors explained $71.2 \%$ of the total variance of the 45 initial items. Applying the fourdimensional structure, the principal component analysis revealed 19 items (at least four items per dimension) with a factor loading higher than 0.55 on the expected dimension, and a cross-factor loading lower than 0.33 on the other dimensions. Accordingly, we deleted all the items that had higher cross-loadings or low loadings on the intended dimension from further analysis (see Table A2 in the appendix for the overview of the results). Next, we checked the reliability analysis of each subdimension that overall showed a high reliability (Cronbach's $\alpha \geq 0.78$ for all four subdimensions). In a second step, we conducted a confirmatory factor analysis with the second subsample using lavaan (Rosseel 2012), an add-on package of R, to validate the expected four-dimensional structure with a second-order public value factor. Here, we used three common fit indices to identify how well the proposed model fits the data: the comparative fit index (CFI), the Tucker-Lewis index (TLI), and the root mean square error of approximation (RMSEA) with its $90 \%$ confidence interval. The CFI and TLI cutoff values of 0.90 indicate an acceptable model fit, and values above 0.95 a good model fit. An RMSEA value of 0.10 and lower indicates an acceptable model fit, and values below 0.08 a good model fit (Hu and Bentler 1999; Kline 2011). As our sample data violates the required assumption of multivariate normality slightly, we used a maximum likelihood estimator with robust standard errors and a Satorra-Bentler scaled test statistic (Satorra and Bentler 1994). Overall, our analyses reveal a very good model fit $(C F I=0.981$, $T L I=0.978$, RMSEA $[90 \%-\mathrm{CI}]=0.044[0.018,0.063])$, which validates the proposed four-dimensional structure with a second-order public value factor. 


\section{Step 3: main study}

\section{Method}

The aim of the main study was to further reduce the number of items and to validate the survey scale by testing it on repeatedly tested and on additional organizations to ensure the scale's retest reliability and wide applicability. Moreover, we added additional scales to analyze public value's construct distinctiveness and explanatory power. As in the pre-study, we cooperated with the independent Swiss market research agency intervista to recruit a sample representative for Switzerland. Our final sample consisted of 1299 participants from the German speaking part of Switzerland aged between 18 and 88 years old $(M=54.49, S D=18.44)$, of whom $46.6 \%$ were female. Approximately a quarter of the sample (24.6\%) had a higher education (i.e., university or college). As in the pre-study, the demographic data distribution strongly resembled that of the general Swiss population, indicating a highly representative sample.

For further validation of the scale, we included the two organizations from study 1 to test the retest reliability; then we added a national cooperative (Raiffeisen, a national bank cooperative) and another private organization (Apple, as an example of a non-national organization). At least 273 participants rated each organization. As in study 1 , all the participants started with a familiarity evaluation of the randomly assigned organization on a six-point Likert scale $(1=$ "not familiar at all" to $6=$ "very familiar"). Only participants with a score of at least 4 on the familiarity scale for a given organization were automatically forwarded to the public value items. Here, each participant rated 19 public value statements about one of the four organizations on a six-point Likert scale ( $1=$ "I do not agree" to $6=$ "I agree"). We also included a marker variable (Podsakoff et al. 2003), "I like to think abstractly," to test for possible common method bias.

To analyze the public value concept's distinctiveness, we included a corporate social responsibility (CSR, Currás-Pérez, Bigné-Alcañiz, and Alvarado-Herrera 2009) and a reputation scale (Agarwal, Stackhouse, and Osiyevskyy 2018), as they conceptually overlap with the public value concept, but also show differences. CSR is a highly popular framework in business research that "reflects the social imperatives and the social consequences of business success" (Matten and Moon 2008, 405). Both, the public value and the CSR concept, concern social evaluations that reflect "the relationship between organizations and social collectives" (Meynhardt, Strathoff, et al. $2019,5)$. Moreover, the CSR debate in business research focuses on values that are also typical in the traditional public sector, such as sustainability, social responsibility, or fairness (Van der Wal et al. 2008), and thus could represent a construct similar to public value. Yet, as we argue that public value goes beyond the moral-ethical domain that most CSR values would account for (see also Meynhardt and Gomez 2019), we expect differences between CSR and public value, especially considering the other dimensions identified above.

Reputation is defined as "a collective assessment of a company's attractiveness to a specific group of stakeholders relative to a reference group of companies with which the company competes for resources" (Fombrun 2012, 100; see also Agarwal et al. 2018). It plays a major role in understanding how the public evaluates an organization, and is as important to private as to public organizations (Waeraas and Byrkjeflot 2012). Both, public value and reputation, are "social approval assets with an external locus of control" (Meynhardt, Strathoff, et al. 2019, 13). Yet, although both constructs regard a social collective's evaluations, only public value necessarily encompasses consideration of some form of social collective within each individual evaluation; reputation, in contrast, might build on completely self-focused individual evaluations (Meynhardt, Strathoff, et al. 2019). Additionally, one could argue that reputation is "relative to a reference group of companies with which the company competes for resources" (Fombrun 2012, 100), while public value is relative to the social collective to which the evaluating individual mostly relates (Meynhardt, Strathoff, et al. 2019). Consequently, there can theoretically be overlapping forms of reputation, such as the reputation for being socially ethical (Agarwal et al. 2018), that also consider the social collective and should strongly correlate with public value. Other forms of 
reputation, such as reputation for market prominence (Agarwal et al. 2018), do not directly consider the social collective and, hence, should be less connected to the public value construct. Overall, in investigating the distinctiveness, we expected the public value scale to correlate highly with the CSR and reputation scales, but also to show specific differences.

Further, participants responded to scales concerning their attitudes, intentions, and behaviors toward the organizations (i.e., trust, loyalty, satisfaction, past consumption frequency, willingness to pay more, and word-of-mouth scales, as in Walsh and Beatty 2007, see also Donahue and Miller 2006). We included these measures to test the effectiveness and explanatory power of public value, bearing in mind fundamental differences of public and private sector organizations. We only used measure which are - within certain limits - applicable to all organizations. Even though, willingness to pay more and consumption frequency are commonly used as outcome measures of private companies, these two indicators are also of growing importance for public organizations evaluations as well. For example, Donahue and Miller $(2006,395)$ state that the "constrained public budgets and increasing demand for public services impose a condition of fiscal stress on local governments, which contend with a persistent mandate to do more with less." Accordingly, also public organizations should be interested in the willingness to pay (e.g. taxes) and the consumption frequency (e.g. use of public services) of their clients. Overall, high public value scores should reflect a high basic need fulfillment, which should be connected theoretically to positive attitudes and behavior (Epstein 2003). Conversely, low public value scores should reflect a low basic need fulfillment, which should result in negative attitudes and behaviors. We, therefore, hypothesized that public value would correlate with these client and customer attitudes and behaviors. Finally, participants gave their demographic data, which included age, gender, education level, and income.

\section{Analysis and results}

First of all, we examined the factor loadings of the 19 items remaining after completion of the pre-study described above, using exploratory principal component analysis for each of the four organizational cases. As in study 1, we used the Velicer's (1976) minimum average partial (MAP) analysis and a scree plot analysis to verify whether the collected data fits the hypothesized fourdimensional structure of public value. Again, the analyses supported the structural hypothesis, which implies that public value, as measured by the chosen items, can be structured in four basic need dimensions. Specifically, the MAP analysis showed that the four factors explain $85.6 \%$ of the variance. Moreover, we intended to have an equal number of items per dimension, as well as the best possible parsimoniousness of the scale to improve the usability of the scale in future empirical research. As Kenny (1979) recommended that a latent measure should consist of at least three items, we decided to limit the number to the three best fitting items per dimension (i.e., the complete scale consists of twelve items). Accordingly, we chose the twelve best fitting items based on the principal component analysis (see Table A3 in the appendix for full results). Next, we tested these remaining twelve best fitting items with an additional principal component analysis that revealed high factor loadings $(\geq 0.67)$ on the intended factors and low cross-loadings $(\leq 0.37$; see Table 2 for results).

Further, the reliability analyses of the final twelve-item scale showed very high values for every dimensional subscale applied to each organization (Cronbach's $\alpha \geq 0.84$ ). The retest reliability analyses of the public value results of the two repeatedly measured organizations were also high $(r \geq .82, p<.001)$. Next, we conducted a confirmatory factor analysis using lavaan to validate the expected structure of the remaining 12 items. We used a maximum likelihood estimator with robust standard errors and a Satorra-Bentler scaled test statistic, because our data slightly violated the required assumption of multivariate normality (Satorra and Bentler 1994). A good overall model fit validates the expected four-dimensional structure with a second-order public value 
Table 2. Principal component analysis of the 12 final items using Varimax with Kaiser Normalization as rotation method.

\begin{tabular}{lcccc}
\hline & 1 & 2 & 3 & 4 \\
\hline [The organization X] contributes to the quality of life in Switzerland. & .290 & .372 & .669 & .211 \\
[The organization X] is enjoyable for people in Switzerland. & .200 & .309 & .805 & .254 \\
[The organization X] is pleasant for people in Switzerland. & .318 & .248 & .788 & .300 \\
[The organization X] is professionally recognized in Switzerland. & .201 & .134 & .295 & .808 \\
[The organization X] is economically viable. & .036 & .160 & .111 & .906 \\
[The organization X] performs well in its core business. & .440 & .175 & .365 & .625 \\
[The organization X] contributes to social cohesion in Switzerland. & .389 & .778 & .306 & .144 \\
[The organization X] creates a community in Switzerland. & .318 & .809 & .297 \\
[The organization X] has a positive effect on social relationships in Switzerland. & .354 & .788 & .273 \\
[The organization X] behaves decently. & .841 & .309 & .266 \\
[The organization X] is fair. & .859 & .344 & .221 \\
[The organization X] acts ethically correct. & .850 & .363 & .234 & .198 \\
\hline
\end{tabular}

Note. Coefficients with the highest factor loading are marked in bold.

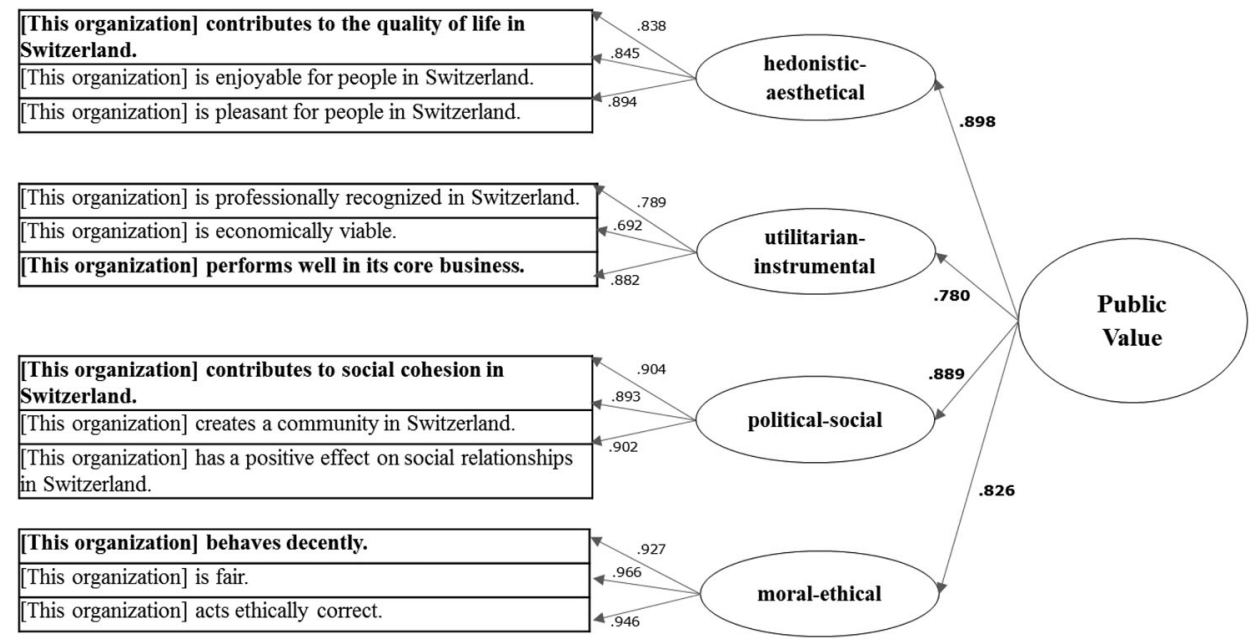

Figure 1. Confirmatory factor analysis of the final 12 items.

Note. Numbers represent the standardized path coefficients. All path coefficients are highly significant with $p<0.001$. Items of the short scale are marked bold.

factor $(C F I=0.963, T L I=0.951, R M S E A[90 \%-C I]=0.081[0.075,0.087])$. Figure 1 shows the final model with its standardized coefficients.

Since we used the same method to measure all items of our study, a common method bias could partly affect our results (Podsakoff et al. 2003). A common method bias implies that the measurement method, rather than the constructs the measures represent, is responsible for a high share of the variance explained (Podsakoff et al. 2003). However, Jakobsen and Jensen (2015) state that the "common method variance does not create or inflate interaction effects. In contrast, common method variance can attenuate interaction effects. Therefore, if one finds an interaction effect when common method variance is present, it should be taken as strong evidence that the interaction effect exists" (24). Additionally, statistical tests like the "CFA marker technique may provide some indication of the presence or absence of common method variance, which may contribute to the overall evaluation of common method bias in the analysis" (25). Even though some scholars have criticized the marker variable technique for its limitation in correcting the bias, it remains one of the most efficient ways to indicate if there is a common method problem (Jakobsen and Jensen 2015; Podsakoff et al. 2003). While sharing the same measure, a marker variable should be, theoretically, unrelated to the main constructs. Hence, the correlation with the main constructs is expected to represent the common method variance. Following prior research 
Table 3. Means, standard deviations, Cronbach's $\alpha$ and correlation coefficients for nomological validity analyses $(n=1299)$.

\begin{tabular}{|c|c|c|c|c|c|c|c|c|c|}
\hline & $M$ & $S D$ & $\alpha$ & 1 & 2 & 3 & 4 & 5 & 6 \\
\hline 1. Public value scale & 4.06 & 1.11 & .93 & & & & & & \\
\hline 2. Moral-ethical dimension & 3.75 & 1.55 & .96 & .880 & & & & & \\
\hline 3. Political-social dimension & 3.51 & 1.38 & .92 & .891 & .740 & & & & \\
\hline 4. Utilitarian-instrumental dim. & 4.87 & 1.02 & .84 & .757 & .528 & .527 & & & \\
\hline 5. Hedonistic-aesthetical dim. & 4.10 & 1.22 & .89 & .881 & .655 & .732 & .654 & & \\
\hline 6. Public value short & 3.99 & 1.24 & .86 & .974 & .872 & .714 & .857 & .871 & \\
\hline 7. Corporate social responsibility & 3.52 & 1.33 & .95 & .839 & .843 & .763 & .536 & .674 & .831 \\
\hline 8. Reputation & 3.94 & 1.02 & .91 & .775 & .640 & .652 & .698 & .688 & .739 \\
\hline 9. Product/Service efficacy dim. & 3.84 & 1.20 & .86 & .773 & .683 & .637 & .651 & .683 & .637 \\
\hline 10. Societal ethicality dimension & 3.52 & 1.21 & .87 & .814 & .775 & .747 & .555 & .673 & .747 \\
\hline 11. Market prominence dimension & 4.44 & 1.21 & .91 & .372 & .160 & .264 & .559 & .384 & .264 \\
\hline 12. Marker variable & 4.07 & 1.35 & - & .001 & -.055 & .000 & .073 & .013 & -.004 \\
\hline
\end{tabular}

Note. All correlations were significant with $p<.01$, except correlations with the marker variable (here only the correlation with the hedonistic-aesthetical dimension and moral-ethical dimension was significant with $p<.05$ ).

(de Boer, Eshuis, and Klijn 2018; Jakobsen and Jensen 2015; Lindell and Whitney 2001; Podsakoff et al. 2003), we added a common latent factor to our conceptual model, with all items, including the marker variable, loading on one factor (which should account for the common method bias). This analysis revealed a small, but significant, common latent factor that implies a possible common method bias $(\beta=.07, p=.002)$. Next, we compared the conceptual model to the new model, including the common latent factor (de Boer et al. 2018). Here, the ANOVA shows no significant difference in the $\chi^{2}$ of the two models $(\chi 2$ difference $=18.621, d f=11, p=0.0683$ ). This means that the inclusion of a common latent factor does not result in significant differences to the original model, meaning the influence of the common method bias is negligible.

Besides the twelve-item public value scale, we created a short scale consisting of four items. For this purpose, we selected one item from each public value dimension, which best represents the overall content of the dimension (see bold items in Figure 1). This short scale correlated strongly with the overall public value scale $(r=.97, p<.001)$ and the sub-scales $(r \geq .71, p<$ $.001)$, implying high comparability to the full scale, although it does not allow the same degree of specification within the dimensions. Also, the validity of the short scale was good (Cronbach's $\alpha$ $=.86)$.

As we also aimed to better understand the public value construct's distinctiveness as measured by the public value scale and compared to related social evaluation constructs, we included a CSR and a reputation scale in the survey, as they show conceptual overlap, but simultaneously some marked differences (Meynhardt, Strathoff, et al. 2019). As expected, CSR and reputation overall correlated strongly with public value (CSR: $r=0.84, p<0.001$; reputation: $r=0.78, p<0.001$ ). Also, the public value short scale showed high correlations with CSR $(r=0.83, p<0.001)$ and reputation $(r=0.74, p<0.001)$. Yet, an examination of the subdimensions of public value revealed some substantial distinctiveness. Specifically, we found that public value's moral-ethical dimension correlates significantly higher to CSR $(r=0.84, p<0.001)$ compared to the utilitarianinstrumental dimension $(r=0.54, p<0.001$, difference $z=19.16, p<.001)$. Analyzing the correlation between reputation and public value in more detail, we found public value to correlate stronger with the "product and service efficacy" $(r=0.77, p<0.001)$ and "societal ethicality" $(r=0.81, p<0.001)$ dimensions of reputation compared to the "market prominence" dimension of reputation ( $r=0.37, p<0.001$, difference to product and service efficacy: $z=24.48, p<.001$; difference to societal ethicality: $z=28.26, p<.001)$. We summarize all correlations of the discussed constructs in Table 3.

To further reflect the distinctiveness of public value and its subdimensions from CSR and reputation, we conducted an additional exploratory factor analysis with items from the three scales. The scree-plot analysis implied six factors accounting for $81.4 \%$ of the total variance. As presented in Table 4, the 12 final public value items in this analysis also formed four independent 
Table 4. Principal component analysis of the 12 final items of the public value scale, 9 items of the reputation scale, and 6 items of the CSR scale using Varimax with Kaiser normalization as rotation method.

\begin{tabular}{|c|c|c|c|c|c|c|}
\hline & 1 & 2 & 3 & 4 & 5 & 6 \\
\hline Hedonistic-aesthetical1 & .396 & .163 & .360 & .620 & .219 & .150 \\
\hline Hedonistic-aesthetical3 & .289 & .179 & .263 & .767 & .153 & .218 \\
\hline Hedonistic-aesthetical4 & .370 & .160 & .189 & .731 & .230 & .277 \\
\hline Utilitarian-instrumental1 & .226 & .352 & .088 & .275 & .128 & .716 \\
\hline Utilitarian-instrumental3 & .098 & .469 & .119 & .096 & .078 & .735 \\
\hline Utilitarian-instrumental4 & .380 & .186 & .149 & .345 & .280 & .620 \\
\hline Political-social1 & .523 & .072 & .679 & .293 & .133 & .120 \\
\hline Political-social2 & .478 & .127 & .708 & .288 & .121 & .106 \\
\hline Political-social4 & .478 & .153 & .704 & .252 & .150 & .165 \\
\hline Moral-ethical1 & .705 & -.085 & .295 & .163 & .324 & .334 \\
\hline Moral-ethical2 & .727 & -.065 & .326 & .122 & .349 & .287 \\
\hline Moral-ethical3 & .728 & -.092 & .347 & .122 & .313 & .259 \\
\hline $\operatorname{csr} 1$ & .786 & .147 & .150 & .209 & .152 & .112 \\
\hline $\operatorname{csr} 2$ & .894 & .083 & .153 & .169 & .126 & .100 \\
\hline $\operatorname{csr} 3$ & .826 & .213 & .042 & .242 & .039 & .126 \\
\hline $\operatorname{csr} 4$ & .870 & .076 & .207 & .190 & .159 & .144 \\
\hline $\operatorname{csr} 5$ & .768 & .150 & .285 & .241 & .209 & .092 \\
\hline $\operatorname{csr} 6$ & .854 & .070 & .257 & .178 & .184 & .146 \\
\hline Reputation/Efficacy1 & .458 & .283 & .179 & .195 & .608 & .163 \\
\hline Reputation/Efficacy2 & .440 & .309 & .163 & .240 & .629 & .192 \\
\hline Reputation/Efficacy3 & .374 & .313 & .070 & .246 & .629 & .189 \\
\hline Reputation/Ethicality4 & .711 & .213 & .261 & .209 & .359 & .087 \\
\hline Reputation/Ethicality5 & .444 & .464 & .255 & .160 & .399 & .017 \\
\hline Reputation/Ethicality6 & .834 & .148 & .209 & .145 & .224 & .036 \\
\hline Reputation/Prominence7 & .065 & .839 & .025 & .142 & .084 & .153 \\
\hline Reputation/Prominence8 & .095 & .877 & .095 & .066 & .162 & .159 \\
\hline Reputation/Prominence9 & .037 & .879 & .038 & .080 & .119 & .200 \\
\hline
\end{tabular}

Note. Coefficients with the highest factor loading are marked in bold.

factors representing the four public value dimensions. All six CSR items loaded clearly on the same factor as the moral-ethical public value dimension (factor loadings $\geq 0.77$ and cross-loadings $\leq 0.29$ ). The reputation scale's nine items distributed to three different factors depending on their theoretical subdimensions. The three items of the reputation subdimension "product and service efficacy" loaded highly on an additional factor that is unrelated to the public value items (factor loadings $\geq 0.61$ ), but these items also had high cross-loadings with the moral-ethical dimension $(0.37-0.46)$. Two items of the reputation subdimension "societal ethicality" loaded on the same factor as the public value items of the moral-ethical dimension (factor loading 0.71 and 0.83). However, one item of this subdimension ("This company seems to make an effort to create new jobs") had high loadings on three different factors, showing a strong interaction with the moral-ethical factor (where the related reputation subdimension's two other items also loaded), as well as with two other factors (where the other reputation items loaded). The three items of the reputation subdimension "market prominence" loaded on a factor not related to the public value items, showing very high factor loadings $(\geq 0.84)$ and low cross-loading $(\leq 0.15)$.

We subsequently analyzed the explanatory power of the public value scale by examining its expected correlations with other social evaluations and client/customer attitudes and behaviors, such as satisfaction, trust, and consumption frequency. As shown in Table 5, all scales tested correlated significantly with the overall public value scale $(r \geq 0.39, p<0.001)$ and the four subdimensions $(r \geq 0.28, p<0.001)$. Also, the public value short scale correlated significantly with all client/customer variables tested $(r \geq 0.39, p<0.001)$. Further, we analyzed the correlations with the theoretically unrelated marker variable to check for a possible common method bias and discriminant validity. As expected, we found no significant correlation with the overall public value scale $(r=0.001, p=0.969)$ nor with the public value short scale $(r=0.000, p=0.992)$, and negligible correlations with the subdimension $(r=-0.06-0.07 p \geq 0.048)$. 
Table 5. Means, standard deviations, and correlation coefficients for construct validity analyses $(n=1299)$.

\begin{tabular}{|c|c|c|c|c|c|c|c|c|c|}
\hline & M & $S D$ & $\alpha$ & 1 & 2 & 3 & 4 & 5 & 6 \\
\hline 1. Public value scale & 4.06 & 1.11 & .93 & & & & & & \\
\hline 2. Moral-ethical dimension & 3.75 & 1.55 & .96 & .880 & & & & & \\
\hline 3. Political-social dimension & 3.51 & 1.38 & .92 & .891 & .740 & & & & \\
\hline 4. Utilitarian-instrumental dimension & 4.87 & 1.02 & .84 & .757 & .528 & .527 & & & \\
\hline 5. Hedonistic-aesthetical dimension & 4.10 & 1.22 & .89 & .881 & .655 & .732 & .654 & & \\
\hline 6. Public value short & 3.99 & 1.24 & .86 & .974 & .872 & .714 & .857 & .871 & \\
\hline 7. Trust & 3.64 & 1.61 & - & .790 & .765 & .650 & .591 & 677 & .781 \\
\hline 8. Loyalty & 3.37 & 1.70 & .94 & 674 & .603 & .591 & .473 & 624 & .673 \\
\hline 9. Satisfaction & 3.47 & 0.76 & .86 & .763 & .687 & .583 & .662 & .5691 & .750 \\
\hline 10. Consumption frequency & 4.28 & 1.83 & - & .391 & .276 & .321 & .311 & .448 & .393 \\
\hline 11. Willingness-to-pay & 3.10 & 1.73 & - & .522 & .432 & .460 & .369 & .523 & .522 \\
\hline 12. WOM & 3.64 & 1.60 & .97 & .814 & .763 & .681 & .619 & .707 & .797 \\
\hline 13. Marker variable & 4.07 & 1.35 & - & .001 & -.055 & .000 & .073 & .013 & -.004 \\
\hline
\end{tabular}

Note. All correlations were significant with $p<.01$, except correlations with the marker variable (here only the correlation with the hedonistic-aesthetical dimension and moral-ethical dimension was significant with $p<.05$ ).

Furthermore, we analyzed the public value scale's explanatory power in comparison to the CSR and reputation scales by using regression analyses. We conducted separate regression analyses with public value, CSR, or reputation as predictors of the client/customer variables. The analyses showed that the public value scale explained up to $66.2 \%$ of the tested client/customer variables' variance $\left(R^{2}=0.153\right.$ (consumption frequency) - 0.662 (word-of-mouth)). Moreover, the public value scale showed the highest regression coefficients compared to reputation and CSR. Next, we conducted regression analyses to predict the client/customer variables through a combination of the public value scale and the CSR scale. Here, we noticed that adding CSR as a predictor showed no to very little improvement. The explained variance increased from only $0.0 \%$ (willingness-to-pay) to $2.7 \%$ (trust), when we added CSR to public value as an additional predictor. When we controlled for public value, CSR's influence strongly dropped. Moreover, it even became non-significant in predicting willingness-to-pay and, interestingly, even significantly negative in predicting consumption frequency. We also conducted regression analyses to predict the client/customer variables through a combination of the public value scale and the reputation scale. Here we found that adding reputation to public value as a predictor also showed only small improvements. The explained variance increased from $0.5 \%$ (consumption frequency) to $2.9 \%$ (satisfaction). The regression coefficients of public value and reputation remained positive and highly significant, which implies that reputation adds significantly, yet not in a major way, to public value, when explaining client/customer outcomes (Tables 6 and 7).

\section{Discussion}

Overall, the analyses reveal first support for the proposed four-dimensional public value scale. Testing the public value scale on a public evaluation of four organizations from different sectors by means of two representative samples, implies good reliability and validity of the newly developed public value scale. The analyses repeatedly validated a four-dimensional structure with a second-order public value factor. We identified three best fitting items for each dimension, resulting in overall 12 items. Additionally, we provided a shorter version of four items that in our analysis also showed good validity and reliability for measuring the overall public value construct. Yet, only the full scale appropriately specifies the subdimensions and would thereby allow us to research the impact of each separately. Both public value scales provide a validated measure for future empirical research that aims to test the public value of organizations in the private, as well as the public sector.

We also applied this newly developed public value scale to test empirically the distinctiveness of public value in relation to other constructs. Specifically, we looked at how public value is 
Table 6. Regression analysis of public value (PV) and CSR on client/customer variables.

\begin{tabular}{|c|c|c|c|c|c|c|c|c|c|c|c|c|}
\hline & \multicolumn{2}{|c|}{ Trust } & \multicolumn{2}{|c|}{ Loyalty } & \multicolumn{2}{|c|}{ Satisfaction } & \multicolumn{2}{|c|}{ Frequency } & \multicolumn{2}{|c|}{ WTP } & \multicolumn{2}{|c|}{ WOM } \\
\hline & ß & $R^{2}$ & ß & $\mathrm{R}^{2}$ & B & $R^{2}$ & B & $R^{2}$ & B & $R^{2}$ & ß & $\mathrm{R}^{2}$ \\
\hline $\begin{array}{c}\text { Model } 1 \\
\text { PV }\end{array}$ & .790 & .625 & .674 & .454 & .763 & .582 & .391 & .153 & .522 & .273 & .814 & .662 \\
\hline $\begin{array}{c}\text { Model } 2 \\
\text { CSR }\end{array}$ & .753 & .567 & 619 & .384 & .675 & .455 & .298 & .089 & .437 & .191 & .767 & .588 \\
\hline $\begin{array}{c}\text { Model } 3 \\
\text { PV } \\
\text { CSR }\end{array}$ & $\begin{array}{l}.536 \\
.303\end{array}$ & .652 & $\begin{array}{l}.522 \\
.181\end{array}$ & .464 & $\begin{array}{l}.665 \\
.116\end{array}$ & .586 & $\begin{array}{c}.476 \\
-.102\end{array}$ & .154 & $\begin{array}{c}.526 \\
-.004\end{array}$ & .273 & $\begin{array}{l}.577 \\
.282\end{array}$ & .686 \\
\hline
\end{tabular}

Note. All standardized coefficients $(B)$ were significant with $p<.03$, except the coefficients in Model 3 of CSR on satisfaction and willingness-to-pay (coefficients marked in bold).

Table 7. Regression analysis of Public Value and Reputation on client/customer variables.

\begin{tabular}{|c|c|c|c|c|c|c|c|c|c|c|c|c|}
\hline & \multicolumn{2}{|c|}{ Trust } & \multicolumn{2}{|c|}{ Loyalty } & \multicolumn{2}{|c|}{ Satisfaction } & \multicolumn{2}{|c|}{ Frequency } & \multicolumn{2}{|c|}{ WTP } & \multicolumn{2}{|c|}{ WOM } \\
\hline & B & $R^{2}$ & $\beta$ & $R^{2}$ & B & $R^{2}$ & $\beta$ & $\mathrm{R}^{2}$ & $\beta$ & $R^{2}$ & $\beta$ & $R^{2}$ \\
\hline $\begin{array}{l}\text { Model1 } \\
\text { PV }\end{array}$ & .790 & .625 & .674 & .454 & .763 & .582 & .391 & .153 & .522 & .273 & .814 & .662 \\
\hline $\begin{array}{l}\text { Model } 2 \\
\quad \text { Reputation }\end{array}$ & .689 & .475 & .595 & .354 & .699 & .489 & .351 & .123 & .484 & .235 & .734 & .539 \\
\hline $\begin{array}{l}\text { Model } 3 \\
\text { PV } \\
\text { Reputation }\end{array}$ & $\begin{array}{l}.641 \\
.192\end{array}$ & 639 & $\begin{array}{l}.534 \\
.181\end{array}$ & .467 & $\begin{array}{l}.554 \\
.270\end{array}$ & .611 & $\begin{array}{l}.297 \\
.121\end{array}$ & .158 & $\begin{array}{l}.368 \\
.199\end{array}$ & .287 & $\begin{array}{l}.614 \\
.258\end{array}$ & .689 \\
\hline
\end{tabular}

Note. All standardized coefficients $(B)$ were significant with $p<.01$

distinct from CSR and reputation. These concepts are theoretically strongly connected to public value (Meynhardt, Strathoff, et al. 2019; Meynhardt and Gomez 2019; Van der Wal et al. 2008) because, as public value, they present the public's positive social evaluations of organizations. Whereas the concept of public value originated from and is still popular in public management research (Moore 1995), it is less known in research on private organizations' management (Meynhardt and Gomez 2019; Van der Wal et al. 2008). Conversely, concepts such as CSR or reputation are highly popular in private management or business ethics research, but applied less in the public management field. However, as the sectoral lines between the public and private sectors become blurred (Meynhardt 2015; Moulton 2009), all these concepts could theoretically be applied to private as well as public organizations. Hence, the question arises as to how these concepts differ, and which advantages they offer.

In our study, we could identify first conceptual differences between these concepts. CSR, we found, correlated most strongly with the moral-ethical dimension of public value, implying that CSR especially represents moral or ethical behavioral aspects of organizations but, comparatively, neglects the other needs-based dimensions of public value. For reputation, we found, the societal ethical dimension of reputation loads on the same factor as the public value and the CSR scales' moral-ethical dimension. Yet, the other two dimensions (product/service efficacy and market prominence) load on two separate factors with low cross-loadings on the public value and the CSR scales' factors. Especially, the reputation dimension market prominence, which "refers to the firm's current and future performance and growth prospects relative to competition" (Agarwal et al. 2018, 903), has very low correlations with the public value scale. That implies that although public value explains a great deal of a company's reputation, it neglects important parts. In sum, the analyses give first interesting insights into public value's distinctive features in comparison to the constructs CSR and reputation. Overall, we find that CSR and the societal ethicality dimension of reputation cover public value's moral-ethical dimension very well, but in relative terms neglect the other three dimensions of public value. These three underrepresented public value 
dimensions are as important as the well-covered moral-ethical dimension to fully understand human evaluations, because they all represent basic human needs.

Our study additionally tested the public value scale's explanatory power. We hypothesized that public value would correlate with various client or customer attitudes and behaviors. As expected, the public value scale correlates significantly with all the tested variables (trust, loyalty, satisfaction, past consumption frequency, willingness to pay more, word-of-mouth). The correlation with trust, loyalty, satisfaction, and word-of-mouth is the highest when the organization has a high overall public value score, (i.e., if the organization manages to create public value in all four dimensions). Interestingly, consumption frequency and willingness-to-pay have the highest correlation with the hedonistic-aesthetical dimension - even higher than with the overall public value score. However, the other client/customer variables also mostly show the highest correlation with the hedonistic-aesthetical dimension, more so than with the other subdimensions.

First, these results imply that public value does not leave people untouched. As Meynhardt (2009) suggests, public value can positively or negatively influence how people experience basic need fulfillment, thereby affecting individuals' motivation, attitudes, and behaviors. If an organization's public value is high, it should add to need fulfillment and result in positive attitudes, such as satisfaction, good intentions, and behaviors such as word-of-mouth or consumption. In contrast, if the organization's public value is low, people's basic needs are likely to be less satisfied, and the individual might develop negative attitudes and behaviors, such as distrust, negative word-of-mouth or restrained consumption. The analyses' results corroborate these assumption, which implies that public value has a strong explorative power of various consumer or client attitudes and behaviors.

Second, we find an imbalance between positive attitudes and actual market behavior. Although people are more satisfied, trustful, and loyal when the basic needs of all four dimensions are fulfilled, the hedonistic-aesthetical dimension appears to matter most in market behavior. This finding implies that people prefer to invest in products and services that are enjoyable, pleasant, and contribute to their quality of life. One explanation could be that although all four dimensions are built on basic needs, the need to maximize pleasure and avoid pain is the most instinctive one. This could result in faster and easier processing. In times of market plenitude, clients or customers could simply take the easy way in deciding: What would be most enjoyable? The motivation to act on morality, belonging, or good quality could be limited due to choice overload and the complexity to find the right indicators. Further, marketers appear mostly focused on the hedonistic-aesthetical dimension. Quickly won pleasure seems to be easier to communicate, and is seemingly more successful, than other human needs.

Another finding is that the public value scale is a better predictor of most client/customer variables than is CSR and reputation. Specifically, the public value scale explains more of the client/ customer variables' variance than CSR or reputation does. Adding CSR or reputation to public value as a predictor brought either no or very slight increases in the explaining the variance of all consumer variables. These results imply that the public value scale is not only helpful in predicting important customer or client attitudes and behaviors per se, but could also be superior to popular constructs such as CSR and reputation. A possible explanation is that the public value concept fully reflects human basic need fulfillment, which serves as an antecedent to positive attitudes and behaviors (Epstein 2003). As discussed before, CSR and reputation focus mostly on the moral-ethical dimension, neglecting other important basic needs. For example, the CSR and reputation constructs do not represent the hedonistic-aesthetical dimension at all, while we find it to be the most successful in predicting prior consumption frequency, willingness-to-pay, and other positive attitudes toward an organization. Interestingly, we also find that CSR's positive effect on the client/customer variables becomes insignificant (for willingness-to-pay) or even significantly negative (for prior consumption frequency) when controlled for public value. This implies that moral-ethical or socially responsible behavior is not sufficient to satisfy customers or clients and 
to evoke positive behavior. The other basic human needs also, to some degree, have to be fulfilled.

Finally, the public value scale and its subdimensions' non-significant to very low correlations with the marker variable present a good divergent validity, as these concepts should, according to theory, indeed not correlate. The scale and its dimensions' low correlations with the marker variable imply that the variance explained by the common method is rather low, and that a possible common method bias' influence is highly limited.

\section{Limitations and further research}

According to Meynhardt (2009), the public value conceptualization based on basic needs is not bound to any specific institutional sector or cultural context. In our study, we tested the public value scale on four different organizations in different sectors (national and international private organizations, a national cooperative organization, and a public service organization), which implies broad applicability. Yet further research is needed to better understand and compare the applicability of the scale on organizations in different sectors, or industries. Moreover, we only tested the scale in Switzerland. Although theory suggests that the four basic human needs are independent of country or culture (Epstein 2003; Meynhardt 2009), further studies are needed to validate the scale in different cultural contexts. Additionally, we find the first indications that the hedonistic-aesthetical dimension influences market behavior the most (such as willingness to pay and consumption frequency). We need more research to properly understand why and under which circumstances this preference becomes operative. The hierarchy of values could, for example, differ greatly by culture (Meynhardt 2009), and preference for the hedonistic-aesthetical dimension could apply predominantly to affluent and individualistic societies (e.g., Switzerland) rather than to developing countries. The latter, instead, might value the utilitarian-instrumental dimension more, or collectivistic countries might value the social-political dimension more.

The theoretical foundation further suggests that public value relates to consumers' or clients' attitudes and behaviors toward an organization (Meynhardt 2009). Our analyses find strong connections between public value and trust, loyalty, satisfaction, word-of-mouth, willingness-to-pay, and consumption frequency. The more positively an individual perceives the public value of an organization, the more positive the attitudes and behaviors toward this organization become (e.g., high trust, willingness to pay more for the organization's products or services). Conversely, this also means that the lower the perceived public value, the more negative the individuals' attitudes and behaviors (e.g., distrust, no loyalty). These findings imply that the public value concept has strong explanatory power, although these are only first correlational results and we cannot interpret them as proof of causality. Future research could use experimental study designs to gain a more detailed understanding of public value's effect on societal attitudes and behaviors. Notably, we used positively connoted outcome variables that can be negatively interpreted (e.g., low trust implies distrust), but that do not fully account for the full range of negative outcomes. Accordingly, future research could more specifically test the impact low public value has on negative outcomes on the organizational (e.g., boycott, complaints) or individual levels (e.g., negative emotions, felt helplessness). It is, moreover, important to note, that not all organizations aim to increase consumption frequency (e.g., prisons or rehabilitation clinics). Future research is needed to understand which consequences the public relates to public value within these industries.

Another open question relates to the micro-macro-link of public value. According to theory, each individual public value evaluation is bound to the individual's relation to the public and, thereby, to some degree it reveals what is valuable on a collective level (Meynhardt 2009; Meynhardt et al. 2016). Yet, although individual evaluations are strongly influenced by collective validity, they differ due to individual experiences, available information, or personal preferences or ideologies (Jasinenko, Christandl, and Meynhardt 2020; Meynhardt 2009). Practically, that 
could mean that asking different individuals or groups could result in different public value evaluations. For example, employees in an organization have more insight and information about that organization compared to the general public and, in turn, would evaluate the organization from a different point of view. Similarly, asking women compared to men, could result in different public value evaluations, as when, for example, an organization addresses individuals differently based on gender (e.g., gender specific products/services). Consequently, researchers using the public value scale should attend closely to how their sample selection might bias the public value results. Besides using a sample that is demographically representative to the public in question, researchers could additionally analyze the public value evaluations in relevant sub-groups to understand the level of consensus within the public. Following this method, future research could also examine what kind of organizational or managerial behavior, or which contexts, influence not only the overall public value, but also the consensus about public value between different sub-groups in the larger community. Additionally, future research could approach the question of differences between different sub-groups by adapting the contextual frame of the items. For many items we formulated a national reference frame (i.e., we specified the public in public value as the Swiss public) because it is a widely used context in democratic practices. However, it would be interesting to research whether and under which circumstances individuals perceive public value for other "publics" (e.g., women, muslims, conservatives) to differ from their own national public.

Last but not least, the public value scale offers only one of many possible approaches to gain an understanding of the complex concept of public value. As for almost every method, a quantitative survey method such as we have presented here, has strengths and weaknesses. On the one hand, the public value scale is a highly feasible instrument that enables measuring of many different people's public value perceptions quickly and relatively cost effectively (e.g., in online surveys). Moreover, the measure is applicable independent of culture, sector, or other differences in the public or the evaluated organization, which facilitates comparison between various sectors or cultures. On the other hand, this quantitative measure does not provide the depth of insight that most qualitative methods do. For example, qualitative interviews (e.g., De Graaf and Van der Wal 2008; Yang 2016) or case studies (e.g., Moulton and Feeney 2011) could provide a better understanding of specific public values, the underlying processes, or the interaction with a certain industry's context. Also, methods, such as deliberation studies (e.g., Dryzek et al. 2019), historical analyses (Thompson 2016), or ethnographic studies (Brewer 2000) provide closer observations of the public value macro-level, and are less prone to self-reporting biases.

\section{Practical implications}

From the start, public value has been strongly connected to practical applications. Moore (1995) started this discourse with a strong focus on executive education and providing practical and popular tools. Other studies on public value maintained this practical focus (e.g., Meynhardt 2015). These strategic tools are especially helpful in strategic planning; they are mostly designed to help (public) managers better understand the current or planned future public value contribution. Further, the public value scale focuses specifically on the public perception for which previous public value tools did not account. By placing society at the center of attention, this scale helps managers to gain an external perspective. By using the scale, managers can, for example, identify the discrepancies between management intention and public perception, and cluster them into the four identified dimensions. Furthermore, our results imply that all four basic need dimensions of public value are highly important for positive customer attitudes and behaviors. An isolated strategic focus on only one dimension (such as CSR) could pose a high risk. The public value scale is an empirical survey tool that can cover all four basic needs simultaneously. 


\section{Conclusion}

This article's objective was to develop and validate a public value scale to enable future quantitative research. The empirical survey instrument our study developed and validated, could contribute to further testing, developing, and challenging the public value concept. To develop our scale, we chose Meynhardt's (2009) psychological public value conceptualization, which provides the necessary micro-foundations, a theoretical link to the macro-level, and a feasible four-dimensional structure. Based on this theoretical foundation, we created and tested an initial item pool in two quantitative empirical survey studies. The analyses of the two studies provided first insights on the reliability and validity of the measure. Additionally, we empirically investigated public value's theoretical distinctiveness from related concepts, such as CSR and reputation, that are more widely used in private sector research (Meynhardt, Strathoff, et al. 2019; Meynhardt and Gomez 2019). These findings not only help ensure the public value scale's construct validity, but also contribute to the theoretical discourse on public value distinctiveness. We also empirically test public value's explanatory power on diverse customer/client attitudes and behaviors, finding that an organization's public value is strongly related to various consumer or client attitudes and behaviors, such as consumers' satisfaction with an organization or their consumption frequency.

\section{Acknowledgments}

This scale development is a result of almost a decade of methodological exploration and empirical effort. We wish to cordially thank Stefan Anderer, Steffen Bartholomes, Steven Brieger, Carolin Hermann, Paul Neumann and Pepe Strathoff for their contributions along the way. We are also very grateful to the editor and our reviewers, as well as Johannes Jahn who helped a lot to clarify our approach and the entire argument.

\section{Notes on contributors}

Timo Meynhardt (timo.meynhardt@hhl.de) is Professor and Chair of the Dr. Arend Oetker Chair of Business Psychology and Leadership at HHL Leipzig Graduate School of Management and Managing Director of the Center for Leadership and Values in Society at the University of St. Gallen. He obtained his doctorate and habilitation in business administration at the University of St. Gallen. In his research, Timo Meynhardt links psychological and business management topics, especially in the fields of public value management, leadership, and competency diagnostics.

Anna Jasinenko (anna.jasinenko@unil.ch) is post-doctoral researcher at the University of Lausanne in Switzerland. She holds a PhD in management from the HHL Leipzig Graduate School of Management and a master's degree in psychology from the University of Vienna. In her research, she is mostly interested in how individuals perceive, evaluate, and react to public value, social responsibility, and legitimacy of private and public institutions.

\section{ORCID}

Timo Meynhardt (D) http://orcid.org/0000-0002-2762-7538

Anna Jasinenko (iD http://orcid.org/0000-0002-8376-2558

\section{References}

Agarwal, J., M. Stackhouse, and O. Osiyevskyy. 2018. "I Love That Company: Look How Ethical, Prominent, and Efficacious It is-A Triadic Organizational Reputation (TOR) Scale.” Journal of Business Ethics 153(3):889-910.

Benington, J. 2011. "From Private Choice to Public Value." Pp. 31-49 in Public Value: Theory and Practice, edited by J. Benington and M. H. Moore. Hampshire, UK: Macmillan International Higher Education.

Benington, J. 2015. "Public Value as a Contested Democratic Practice." Pp. 29-48 in Creating Public Value in Practice, edited by J. M. Bryson, B. C. Crosby, and L. Bloomberg. Boca Raton, FL: CRC Press, Taylor and Francis Group. 
Bozeman, B. 1987. All Organizations Are Public. San Francisco, CA: Jossey-Bass.

Bozeman, B. 2007. Public Values and Public Interest: Counterbalancing Economic Individualism. Washington, DC: Georgetown University Press.

Bozeman, B., and M. K. Feeney. 2007. "Toward a Useful Theory of Mentoring: A Conceptual Analysis and Critique.” Administration \& Society 39(6):719-39. doi: 10.1177/0095399707304119.

Bozeman, B., and D. Sarewitz. 2011. "Public Value Mapping and Science Policy Evaluation.” Minerva 49(1):1-23. doi: $10.1007 /$ s1 1024-011-9161-7.

Brewer, J. 2000. Ethnography. Buckingham, Philadelphia: Open University Press.

Bryson, J. M., B. C. Crosby, and Laura Bloomberg. 2014. "Public Value Governance: Moving beyond Traditional Public Administration and the New Public Management.” Public Administration Review 74 (4):445-56. doi: 10. $1111 /$ puar. 12238 .

Bryson, J., A. Sancino, J. Benington, and E. Sørensen. 2017. “Towards a Multi-Actor Theory of Public Value coCreation.” Public Management Review 19(5):640-54. doi: 10.1080/14719037.2016.1192164.

Cattell, R. B. 1966. “The Scree Test for the Number of Factors.” Multivariate Behavioral Research 1(2):245-76. doi: $10.1207 / \mathrm{s} 15327906 \mathrm{mbr} 0102 \_10$.

Currás-Pérez, R., E. Bigné-Alcañiz, and A. Alvarado-Herrera. 2009. "The Role of Self-Definitional Principles in Consumer Identification with a Socially Responsible Company.” Journal of Business Ethics 89 (4):547-64. doi: 10.1007/s10551-008-0016-6.

de Boer, N., J. Eshuis, and E. Klijn. 2018. "Does Disclosure of Performance Information Influence Street-Level Bureaucrats’ Enforcement Style?” Public Administration Review 78(5):694-704. doi: 10.1111/puar.12926.

De Graaf, G., and Z. Van der Wal. 2008. "On Value Differences Experienced by Sector Switchers." Administration \& Society 40(1):79-103. doi: 10.1177/0095399707311785.

Donahue, A. K., and J. M. Miller. 2006. "Experience, Attitudes, and Willingness to Pay for Public Safety." The American Review of Public Administration 36(4):395-418. doi: 10.1177/0275074005285666.

Dryzek, John S., André Bächtiger, Simone Chambers, Joshua Cohen, James N. Druckman, Andrea Felicetti, James S. Fishkin, David M. Farrell, Archon Fung, Amy Gutmann, et al. 2019. "The Crisis of Democracy and the Science of Deliberation." Science (New York, N.Y.) 363(6432):1144-6. doi: 10.1126/science.aaw2694.

Epstein, S. 2003. "Cognitive-Experiential Self-Theory of Personality." Comprehensive Handbook of Psychology 5: 159-84.

Fombrun, C. J. 2012. “The Building Blocks of Corporate Reputation: Definitions, Antecedents, Consequences.” Pp. 94-113 in The Oxford Handbook of Corporate Reputation edited by Michael L. Barnett and Timothy G. Pollock. Oxford: Oxford University Press.

Hartley, J., J. Alford, E. Knies, and S. Douglas. 2017. “Towards an Empirical Research Agenda for Public Value Theory." Public Management Review 19(5):670-85. doi: 10.1080/14719037.2016.1192166.

Hartley, J., A. Sancino, M. Bennister, and S. L. Resodihardjo. 2019. "Leadership for Public Value: Political Astuteness as a Conceptual Link.” Public Administration 97(2):239-49. doi: 10.1111/padm.12597.

Heyde, J. E. 1926. Wert. Eine philosophische Grundlegung. Erfurt, Germany: K. Stenger.

Hu, L., and P. M. Bentler. 1999. "Cutoff Criteria for Fit Indexes in Covariance Structure Analysis: Conventional Criteria versus New Alternatives.” Structural Equation Modeling: A Multidisciplinary Journal 6(1):1-55. doi: 10. 1080/10705519909540118.

Jakobsen, M., and R. Jensen. 2015. “Common Method Bias in Public Management Studies.” International Public Management Journal 18(1):3-30. doi: 10.1080/10967494.2014.997906.

Jasinenko, A., F. Christandl, and T. Meynhardt. 2020. "Justified by Ideology: Why Conservatives Care Less about Corporate Social Irresponsibility.” Journal of Business Research 114 (2020):290-303. doi: 10.1016/j.jbusres.2020. 04.006.

Jørgensen, T. B., and B. Bozeman. 2007. “Public Values: An Inventory." Administration \& Society 39(3):354-81. doi: $10.1177 / 0095399707300703$.

Kenny, D. A. 1979. Correlation and Causality. New York: John Wiley.

Kline, R. B. 2011. Principles and Practice of Structural Equation Modeling. 3rd ed. New York: Guilford Press.

Lindell, M. K., and D. J. Whitney. 2001. “Accounting for Common Method Variance in Cross-Sectional Research Designs.” The Journal of Applied Psychology 86(1):114-21. doi: 10.1037/0021-9010.86.1.114.

Matten, D., and J. Moon. 2008. "Implicit" and "Explicit" CSR: A Conceptual Framework for a Comparative Understanding of Corporate Social Responsibility." Academy of Management Review 33(2):404-24. doi: 10.5465/ amr.2008.31193458.

Meynhardt, T. 2009. "Public Value inside: What is Public Value Creation?" International Journal of Public Administration 32(3-4):192-219. doi: 10.1080/01900690902732632.

Meynhardt, T. 2015. "Public Value - Turning a Conceptual Framework into a Scorecard." Pp. 147-69 in Public Value and Public Administration, edited by John M. Bryson, Barbara C. Crosby, and Laura Bloomberg. Washington, DC: Georgetown University Press. 
Meynhardt, T., and S. Bartholomes. 2011. “(De) Composing Public Value: In Search of Basic Dimensions and Common Ground.” International Public Management Journal 14(3):284-308. doi: 10.1080/10967494.2011. 618389.

Meynhardt, T., J. D. Chandler, and P. Strathoff. 2016. "Systemic Principles of Value co-Creation: Synergetics of Value and Service Ecosystems." Journal of Business Research 69(8):2981-9. doi: 10.1016/j.jbusres.2016.02.031.

Meynhardt, T., and A. Fröhlich. 2019. "More Value Awareness for More (Public) Value: Recognizing How and for Whom Value is Truly Created." Pp. 23-39 in Public Value: Deepening, Enriching, and Broadening the Theory and Practice, edited by A. Lindgreen, N. Koenig-Lewis, M. Kitchener, J. D. Brewer, M. H. Moore, and T. Meynhardt. New York: Routledge.

Meynhardt, T., and P. Gomez. 2019. "Building Blocks for Alternative Four-Dimensional Pyramids of Corporate Social Responsibilities.” Business \& Society 58(2):404-38. doi: 10.1177/0007650316650444.

Meynhardt, T., A. Jasinenko, and T. Grubert. 2019. “The Common Good Balance Sheet on Society's Test Bench Empirical Review of the Democratic Legitimacy of the Common Good Balance Sheet." Zfwu Zeitschrift Für Wirtschafts-Und Unternehmensethik - Journal for Business, Economics \& Ethics 20(3):406-26.

Meynhardt, T., P. Strathoff, A. Fröhlich, and S. A. Brieger. 2019. "Same Same but Different: The Relationship between Organizational Reputation and Organizational Public Value." Corporate Reputation Review 22(4): 144-15. doi: 10.1057/s41299-019-00066-0.

Moore, M. H. 1995. Creating Public Value: Strategic Management in Government. Cambridge, Massachusetts: Harvard University Press.

Moulton, S. 2009. "Putting Together the Publicness Puzzle: A Framework for Realized Publicness." Public Administration Review 69(5):889-900. doi: 10.1111/j.1540-6210.2009.02038.x.

Moulton, S., and M. K. Feeney. 2011. "Public Service in the Private Sector: Private Loan Originator Participation in a Public Mortgage Program.” Journal of Public Administration Research and Theory 21(3):547-72. doi: 10. 1093/jopart/muq001.

O'connor, B. P. 2000. "SPSS and SAS Programs for Determining the Number of Components Using Parallel Analysis and Velicer's MAP Test.” Behavior Research Methods, Instruments, \& Computers 32(3):396-402.

Podger, A. 2017. "Enduring Challenges and New Developments in Public Human Resource Management: Australia as an Example of International Experience." Review of Public Personnel Administration 37(1):108-28. doi: 10. 1177/0734371X17693057.

Podsakoff, P. M., S. B. MacKenzie, J. Lee, and N. P. Podsakoff. 2003. "Common Method Biases in Behavioral Research: A Critical Review of the Literature and Recommended Remedies.” The Journal of Applied Psychology 88(5):879-903. doi: 10.1037/0021-9010.88.5.879.

Rhodes, R., and J. Wanna. 2007. "The Limits to Public Value, or Rescuing Responsible Government from the Platonic Guardians.” Australian Journal of Public Administration 66(4):406-21. doi: 10.1111/j.1467-8500.2007. 00553.x.

Rosseel, Y. 2012. “Lavaan: An R Package for Structural Equation Modeling.” Journal of Statistical Software 48(2): 1-36. doi: 10.18637/jss.v048.i02.

Satorra, A., and P. M. Bentler. 1994. "Corrections to Test Statistics and Standard Errors in Covariance Structure Analysis." Pp. 399-419 in Latent Variables Analysis: Applications to Developmental Research, edited by Alexander von Eye and Clifford C. Clogg. Thousand Oaks, CA: Sage Publications.

Thompson, J. R. 2016. "Public Values in Context: A Longitudinal Analysis of the US Civil Service." International Journal of Public Administration 39(1):15-25. doi: 10.1080/01900692.2015.1004091.

Van der Wal, Z., G. De Graaf, and K. Lasthuizen. 2008. "What's Valued Most? Similarities and Differences between the Organizational Values of the Public and Private Sector." Public Administration 86(2):465-82. doi: 10.1111/j.1467-9299.2008.00719.x.

Van Der Wal, Z., L. Huberts, H. Van den Heuvel, and E. Kolthoff. 2006. "Central Values of Government and Business: Differences, Similarities and Conflicts.” Public Administration Quarterly 30(3/4):314-64.

Velicer, W. F. 1976. "Determining the Number of Components from the Matrix of Partial Correlations." Psychometrika 41(3):321-7. doi: 10.1007/BF02293557.

Waeraas, A., and H. Byrkjeflot. 2012. "Public Sector Organizations and Reputation Management: Five Problems." International Public Management Journal 15(2):186-206. doi: 10.1080/10967494.2012.702590.

Wallmeier, F., B. Helmig, and M. K. Feeney. 2019. "Knowledge Construction in Public Administration: A Discourse Analysis of Public Value." Public Administration Review 79(4):488-99. doi: 10.1111/puar.13005.

Walsh, G., and S. E. Beatty. 2007. "Customer-Based Corporate Reputation of a Service Firm: Scale Development and Validation." Journal of the Academy of Marketing Science 35(1):127-43. doi: 10.1007/s11747-007-0015-7.

Williams, I., and H. Shearer. 2011. "Appraising Public Value: Past, Present and Futures." Public Administration 89(4):1367-84. doi: 10.1111/j.1467-9299.2011.01942.x.

Worthington, R. L., and Ti A. Whittaker. 2006. "Scale Development Research: A Content Analysis and Recommendations for Best Practices." The Counseling Psychologist 34(6):806-38. doi: 10.1177/ 0011000006288127 
Yang, L. 2016. "Worlds Apart? Worlds Aligned? The Perceptions and Prioritizations of Civil Servant Values among Civil Servants from China and The Netherlands." International Journal of Public Administration 39(1):74-86. doi: 10.1080/01900692.2015.1053614.

\section{Appendix}

\section{Public value scale with instructions on the example of Nestlé}

Now we want to focus on the following organization: Nestlé

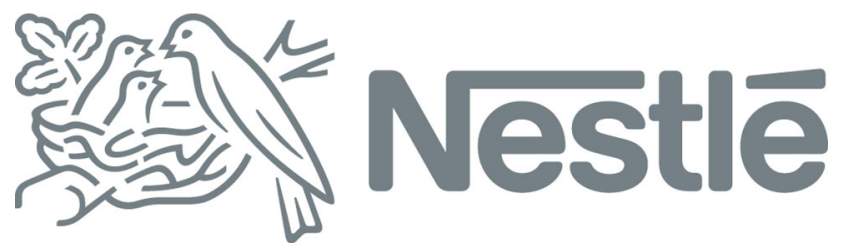

Please indicate, how much you agree with the following statements about this organization, using the 6-point scale below. There are no "right" or "wrong" answers. We are interested in your individual point of view. You can call on your previous experience with this organization's core business (e.g. certain products or services) as a basis for your assessment. Trust your gut feelings when answering.

Do you disagree or agree with the following statements?

1. Nestlé contributes to the quality of life in Switzerland.

1. Nestlé is enjoyable for people in Switzerland.

1. Nestlé is pleasant for people in Switzerland.

1. Nestlé is professionally recognized in Switzerland.

1. Nestlé is economically viable.

1. Nestlé performs well in its core business.

1. Nestlé contributes to social cohesion in Switzerland.

1. Nestlé creates a community in Switzerland.

1. Nestlé has a positive effect on social relationships in Switzerland.

1. Nestlé behaves decently.

1. Nestlé is fair.

1. Nestlé acts ethically correct. don't agree $1-2-3-4-5-6$ I agree don't agree $1-2-3-4-5-6$ I agree don't agree $1-2-3-4-5-6$ I agree don't agree $1-2-3-4-5-6$ I agree don't agree $1-2-3-4-5-6$ I agree don't agree $1-2-3-4-5-6$ I agree don't agree $1-2-3-4-5-6$ I agree don't agree $1-2-3-4-5-6$ I agree don't agree $1-2-3-4-5-6$ I agree don't agree $1-2-3-4-5-6$ I agree don't agree $1-2-3-4-5-6$ I agree don't agree $1-2-3-4-5-6$ I agree 
Table A1. Overview of the 52 initial items in German and English with their intended dimension. The column "Result" represents, if and when an item was dropped in the development procedure: In step 1 we dropped the items due to a high range of "I don't know" answers in study 1. In step 2 we dropped the items due the results of the principal component analysis in study 1 . And in step 3 we dropped the items due to the results of the principal component analysis in study 2 .

\begin{tabular}{|c|c|c|c|}
\hline $\begin{array}{l}\text { Item German } \\
{[\text { Die Organization XY] ... }}\end{array}$ & $\begin{array}{c}\text { Item English } \\
{[\text { The organization } X Y] \ldots}\end{array}$ & Intended dimension & Result \\
\hline $\begin{array}{l}\text {.. trägt zur Lebensqualität } \\
\text { in der Schweiz bei. }\end{array}$ & $\begin{array}{l}\text {... contributes to the } \\
\text { quality of life in } \\
\text { Switzerland. }\end{array}$ & hedonistic-aestethical & $\begin{array}{l}\text { included in final scale; } \\
\text { short scale }\end{array}$ \\
\hline ... verhält sich anständig. & ... behaves decently. & moral-ethical & $\begin{array}{l}\text { included in final scale; } \\
\text { short scale }\end{array}$ \\
\hline $\begin{array}{l}\ldots \text { trägt zum Zusammenhalt } \\
\text { in der Schweiz bei. }\end{array}$ & $\begin{array}{l}\ldots \text { contributes to social } \\
\text { cohesion in Switzerland. }\end{array}$ & political-social & $\begin{array}{l}\text { included in final scale; } \\
\text { short scale }\end{array}$ \\
\hline $\begin{array}{l}\text {... leistet im Kerngeschäft } \\
\text { gute Arbeit. }\end{array}$ & $\begin{array}{l}\text {... performs well in its } \\
\text { core business. }\end{array}$ & utilitarian-instrumental & $\begin{array}{l}\text { included in final scale; } \\
\text { short scale }\end{array}$ \\
\hline $\begin{array}{l}\ldots \text { ist für die Menschen der } \\
\text { Schweiz angenehm. }\end{array}$ & $\begin{array}{l}\ldots \text { is pleasant for the } \\
\text { Swiss people. }\end{array}$ & hedonistic-aestethical & included in final scale \\
\hline $\begin{array}{l}\text {... macht den Menschen in } \\
\text { der Schweiz Freude. }\end{array}$ & $\begin{array}{l}\ldots \text { is enjoyable for people } \\
\text { in Switzerland. }\end{array}$ & hedonistic-aestethical & included in final scale \\
\hline $\begin{array}{l}\ldots \text { handelt ethisch } \\
\text { einwandfrei. }\end{array}$ & $\ldots$ acts ethically correct. & moral-ethical & included in final scale \\
\hline ... handelt fair. & $\ldots$ is fair. & moral-ethical & included in final scale \\
\hline $\begin{array}{l}\text {... schafft eine } \\
\text { Gemeinschaft in } \\
\text { der Schweiz. }\end{array}$ & $\begin{array}{l}\text {... creates a community in } \\
\text { Switzerland. }\end{array}$ & political-social & included in final scale \\
\hline $\begin{array}{l}\text {.. wirkt positiv auf soziale } \\
\text { Beziehungen in } \\
\text { der Schweiz. }\end{array}$ & $\begin{array}{l}\ldots \text { has a positive effect on } \\
\text { social relations in } \\
\text { Switzerland. }\end{array}$ & political-social & included in final scale \\
\hline $\begin{array}{l}\ldots \text { ist in der Schweiz } \\
\text { fachlich anerkannt. }\end{array}$ & $\begin{array}{l}\ldots \text { is professionally } \\
\text { recognized in Switzerland. }\end{array}$ & utilitarian-instrumental & included in final scale \\
\hline $\begin{array}{l}\ldots \text { ist wirtschaftlich stabil. } \\
\ldots \text { hilft, in der Schweiz } \\
\text { Schaden zu vermeiden }\end{array}$ & $\begin{array}{l}\ldots \text { is economically viable. } \\
\ldots \text { helps to prevent damage } \\
\text { in Switzerland. }\end{array}$ & $\begin{array}{l}\text { utilitarian-instrumental } \\
\text { hedonistic-aestethical }\end{array}$ & $\begin{array}{l}\text { included in final scale } \\
\text { step } 1\end{array}$ \\
\hline $\begin{array}{l}\text {.. achtet die Würde } \\
\text { des Einzelnen. }\end{array}$ & $\begin{array}{l}\ldots \text { respects the dignity of } \\
\text { the individual. }\end{array}$ & moral-ethical & step 1 \\
\hline $\begin{array}{l}\ldots \text { setzt sich für } \\
\text { Chancengleichheit ein. }\end{array}$ & $\begin{array}{l}\ldots \text { is committed to equal } \\
\text { opportunities. }\end{array}$ & moral-ethical & step 1 \\
\hline $\begin{array}{l}\text {.. respektiert die } \\
\text { Privatsphäre der } \\
\text { Menschen in der Schweiz. }\end{array}$ & $\begin{array}{l}\ldots \text { respects the privacy of } \\
\text { people in Switzerland. }\end{array}$ & political-social & step 1 \\
\hline $\begin{array}{c}\text {... unterstützt solidarisches } \\
\text { Verhalten in der Schweiz. }\end{array}$ & $\begin{array}{l}\text {... supports solidarity in } \\
\text { Switzerland. }\end{array}$ & political-social & step 1 \\
\hline$\ldots$ arbeitet effizient. & ... works efficiently. & utilitarian-instrumental & step 1 \\
\hline $\begin{array}{l}\text {.. steht für ein günstiges } \\
\text { Aufwand- } \\
\text { Nutzen-Verhältnis. }\end{array}$ & $\begin{array}{l}\ldots \text { stands for a good cost- } \\
\text { benefit balance. }\end{array}$ & utilitarian-instrumental & step 1 \\
\hline $\begin{array}{l}\text {... hilft, Negatives in der } \\
\text { Schweiz zu vermeiden. }\end{array}$ & $\begin{array}{l}\ldots \text { helps to avoid the } \\
\text { negative in Switzerland. }\end{array}$ & hedonistic-aestethical & step 2 \\
\hline $\begin{array}{l}\text {.. ermöglicht positive } \\
\text { Erfahrungen in } \\
\text { der Schweiz. }\end{array}$ & $\begin{array}{l}\text {.. enables positive } \\
\text { experiences in } \\
\text { Switzerland. }\end{array}$ & hedonistic-aestethical & step 2 \\
\hline $\begin{array}{l}\text {... gibt der Bevölkerung in } \\
\text { der Schweiz ein } \\
\text { sicheres Gefühl. }\end{array}$ & $\begin{array}{l}\ldots \text { gives the Swiss public a } \\
\text { sense of security. }\end{array}$ & hedonistic-aestethical & step 2 \\
\hline $\begin{array}{l}\text {.. hilft, den Menschen in } \\
\text { der Schweiz Spass } \\
\text { zu haben. }\end{array}$ & $\begin{array}{l}\ldots \text { helps people in } \\
\text { Switzerland to have fun. }\end{array}$ & hedonistic-aestethical & step 2 \\
\hline $\begin{array}{l}\text {... hilft, den Menschen in } \\
\text { der Schweiz } \\
\text { zu entspannen. }\end{array}$ & $\begin{array}{l}\ldots \text { helps people in } \\
\text { Switzerland to relax. }\end{array}$ & hedonistic-aestethical & step 2 \\
\hline $\begin{array}{l}\ldots \text { ist der Schweizer } \\
\text { Bevölkerung sympathisch. }\end{array}$ & $\begin{array}{l}\ldots \text { is appealing to the } \\
\text { Swiss people. }\end{array}$ & hedonistic-aestethical & step 2 \\
\hline \multirow[t]{2}{*}{$\begin{array}{l}\text { Bevolkerung sympathisch. } \\
\text {... steht für Positives in } \\
\text { der Schweiz. }\end{array}$} & $\begin{array}{l}\ldots \text { stands for the positive in } \\
\text { Switzerland. }\end{array}$ & hedonistic-aestethical & step 2 \\
\hline & & hedonistic-aestethical & step 2 \\
\hline
\end{tabular}


Table A1. Continued.

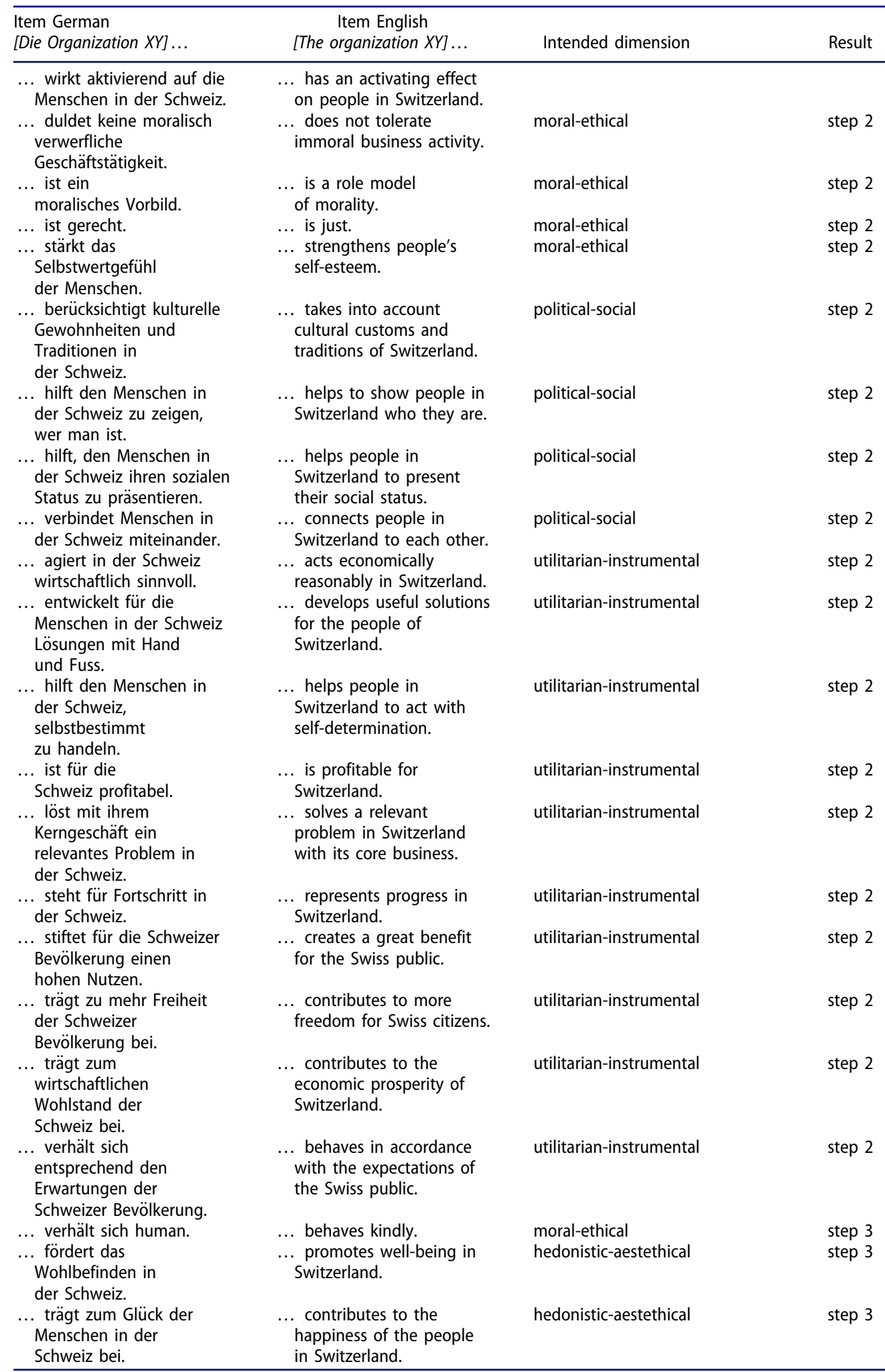


Table A1. Continued.

\begin{tabular}{|c|c|c|c|}
\hline $\begin{array}{l}\text { Item German } \\
{[\text { Die Organization XY] ... }}\end{array}$ & $\begin{array}{c}\text { Item English } \\
{[\text { The organization } X Y] \ldots}\end{array}$ & Intended dimension & Result \\
\hline $\begin{array}{l}\text {... hilft, in der Schweiz } \\
\text { Anschluss zu finden. }\end{array}$ & $\begin{array}{l}\ldots \text { helps to find social } \\
\text { connections in } \\
\text { Switzerland. }\end{array}$ & political-social & step 3 \\
\hline $\begin{array}{l}\text {.. stärkt wichtige soziale } \\
\text { Gruppen in der Schweiz. }\end{array}$ & $\begin{array}{l}\text {... strengthens important } \\
\text { social groups in } \\
\text { Switzerland. }\end{array}$ & political-social & step 3 \\
\hline $\begin{array}{c}\text {.. unterstützt kooperatives } \\
\text { Verhalten in der Schweiz. }\end{array}$ & $\begin{array}{l}\text {... supports cooperation in } \\
\text { Switzerland. }\end{array}$ & political-social & step 3 \\
\hline $\begin{array}{l}\text {.. liefert eine hohe Qualität } \\
\text { für die } \\
\text { Schweizer Bevölkerung. }\end{array}$ & $\begin{array}{l}\ldots \text { delivers high quality for } \\
\text { the Swiss society. }\end{array}$ & utilitarian-instrumental & step 3 \\
\hline
\end{tabular}


Table A2. Study 1: Principal Component Analysis of the 45 remaining items (after deleting 7 items due to too many "I don't know" answers) using Varimax with Kaiser Normalization as rotation method.

\begin{tabular}{|c|c|c|c|c|}
\hline $\begin{array}{l}\text { Item } \\
\text { The [organization } X Y] \ldots .\end{array}$ & hedonistic-aestethical & political-social & moral-ethical & utilitarian-instrumental \\
\hline $\begin{array}{l}\ldots \text { is enjoyable for people in } \\
\text { Switzerland. }\end{array}$ & 0.82 & 0.01 & 0.30 & 0.07 \\
\hline $\begin{array}{l}\text {... contributes to the quality of } \\
\text { life in Switzerland. }\end{array}$ & 0.80 & 0.27 & 0.20 & 0.31 \\
\hline $\begin{array}{l}\ldots \text { is pleasant for the } \\
\text { Swiss people. }\end{array}$ & 0.76 & 0.32 & 0.22 & 0.30 \\
\hline $\begin{array}{l}\text {... contributes to the happiness } \\
\text { of the people in Switzerland. }\end{array}$ & 0.75 & 0.08 & 0.29 & 0.18 \\
\hline $\begin{array}{l}\text {... promotes well-being in } \\
\text { Switzerland. }\end{array}$ & 0.68 & 0.29 & 0.23 & 0.25 \\
\hline $\begin{array}{l}\ldots \text { creates a community in } \\
\text { Switzerland. }\end{array}$ & 0.30 & 0.70 & -0.01 & 0.25 \\
\hline $\begin{array}{l}\text {... supports cooperation in } \\
\text { Switzerland. }\end{array}$ & 0.27 & 0.69 & 0.20 & 0.05 \\
\hline $\begin{array}{l}\text {... helps to find social } \\
\text { connections in Switzerland. }\end{array}$ & 0.26 & 0.68 & 0.23 & 0.09 \\
\hline $\begin{array}{l}\text {... strengthens important social } \\
\text { groups in Switzerland. }\end{array}$ & -0.07 & 0.57 & 0.09 & 0.30 \\
\hline $\begin{array}{l}\ldots \text { contributes to social cohesion } \\
\text { in Switzerland. }\end{array}$ & 0.13 & 0.77 & 0.15 & 0.15 \\
\hline $\begin{array}{l}\ldots \text { has a positive effect on social } \\
\text { relations in Switzerland. }\end{array}$ & 0.29 & 0.79 & 0.12 & 0.14 \\
\hline$\ldots$ acts ethically correct. & 0.22 & 0.12 & 0.64 & 0.08 \\
\hline ... is fair. & 0.20 & 0.11 & 0.74 & 0.17 \\
\hline ... behaves decently. & 0.10 & 0.29 & 0.61 & 0.23 \\
\hline ... behaves kindly. & 0.09 & 0.00 & 0.80 & 0.11 \\
\hline ... is economically viable. & 0.20 & 0.04 & 0.13 & 0.64 \\
\hline $\begin{array}{l}\ldots \text { is professionally recognized in } \\
\text { Switzerland. }\end{array}$ & 0.15 & 0.01 & 0.09 & 0.61 \\
\hline $\begin{array}{l}\text {... delivers high quality for the } \\
\text { Swiss society. }\end{array}$ & 0.29 & 0.22 & 0.06 & 0.71 \\
\hline $\begin{array}{l}\ldots \text { performs well in its } \\
\text { core business. }\end{array}$ & 0.09 & 0.21 & 0.20 & 0.70 \\
\hline $\begin{array}{l}\text {.. helps people in Switzerland } \\
\text { to relax. }\end{array}$ & 0.73 & 0.15 & 0.14 & 0.42 \\
\hline $\begin{array}{l}\ldots \text { gives the Swiss public a sense } \\
\text { of security. }\end{array}$ & 0.70 & 0.35 & 0.07 & 0.26 \\
\hline $\begin{array}{l}\text {... enables positive experiences in } \\
\text { Switzerland. }\end{array}$ & 0.67 & 0.45 & 0.26 & 0.22 \\
\hline $\begin{array}{l}\ldots \text { helps people in Switzerland to } \\
\text { act with self-determination. }\end{array}$ & 0.63 & 0.40 & 0.17 & 0.28 \\
\hline $\begin{array}{l}\ldots \text { has an activating effect on } \\
\text { people in Switzerland. }\end{array}$ & 0.63 & 0.20 & 0.20 & 0.39 \\
\hline $\begin{array}{l}\ldots \text { helps people in Switzerland to } \\
\text { have fun. }\end{array}$ & 0.61 & 0.03 & 0.09 & 0.45 \\
\hline $\begin{array}{l}\ldots \text { is appealing to the } \\
\text { Swiss people. }\end{array}$ & 0.57 & 0.10 & 0.02 & 0.54 \\
\hline $\begin{array}{l}\text {... creates a great benefit for the } \\
\text { Swiss public. }\end{array}$ & 0.57 & 0.15 & 0.26 & 0.56 \\
\hline $\begin{array}{l}\ldots \text { strengthens people's } \\
\text { self-esteem. }\end{array}$ & 0.57 & 0.36 & 0.29 & 0.03 \\
\hline $\begin{array}{l}\ldots \text { helps to avoid the negative in } \\
\text { Switzerland. }\end{array}$ & 0.54 & 0.40 & 0.21 & 0.08 \\
\hline $\begin{array}{l}\ldots \text { contributes to more freedom } \\
\text { for Swiss citizens. }\end{array}$ & 0.48 & 0.27 & 0.02 & 0.62 \\
\hline $\begin{array}{l}\ldots \text { develops useful solutions for } \\
\text { the people in Switzerland. }\end{array}$ & 0.46 & 0.35 & 0.41 & 0.34 \\
\hline $\begin{array}{l}\ldots \text { represents progress in } \\
\text { Switzerland. }\end{array}$ & 0.45 & 0.13 & 0.11 & 0.65 \\
\hline $\begin{array}{l}\ldots \text { stands for the positive in } \\
\text { Switzerland. }\end{array}$ & 0.43 & 0.31 & 0.38 & 0.16 \\
\hline
\end{tabular}


Table A2. Continued.

\begin{tabular}{|c|c|c|c|c|}
\hline $\begin{array}{l}\text { Item } \\
\text { The [organization XY] .... }\end{array}$ & hedonistic-aestethical & political-social & moral-ethical & utilitarian-instrumental \\
\hline$\ldots$ is just. & 0.43 & 0.31 & 0.63 & -0.03 \\
\hline $\begin{array}{l}\text {... contributes to the economic } \\
\text { prosperity of Switzerland. }\end{array}$ & 0.39 & 0.15 & 0.16 & 0.62 \\
\hline$\ldots$ is a role model of morality. & 0.38 & 0.11 & 0.58 & 0.20 \\
\hline $\begin{array}{l}\text {... connects people in Switzerland } \\
\text { to each other. }\end{array}$ & 0.36 & 0.51 & -0.09 & 0.43 \\
\hline $\begin{array}{l}\ldots \text { behaves in accordance with } \\
\text { the expectations of the } \\
\text { Swiss public. }\end{array}$ & 0.35 & 0.19 & 0.19 & 0.42 \\
\hline $\begin{array}{l}\ldots \text { helps to show people in } \\
\text { Switzerland who they are. }\end{array}$ & 0.34 & 0.69 & 0.03 & 0.36 \\
\hline $\begin{array}{l}\ldots \text { does not tolerate immoral } \\
\text { business activity. }\end{array}$ & 0.24 & 0.36 & 0.71 & 0.12 \\
\hline $\begin{array}{l}\ldots \text { helps people in Switzerland to } \\
\text { present their social status. }\end{array}$ & 0.21 & 0.63 & 0.10 & 0.41 \\
\hline $\begin{array}{l}\text {... solves a relevant problem in } \\
\text { Switzerland with its } \\
\text { core business. }\end{array}$ & 0.21 & 0.34 & 0.29 & 0.62 \\
\hline $\begin{array}{l}\text {... acts economically reasonably in } \\
\text { Switzerland. }\end{array}$ & 0.09 & 0.05 & 0.44 & 0.61 \\
\hline$\ldots$ is profitable for Switzerland. & -0.01 & 0.10 & 0.41 & 0.60 \\
\hline $\begin{array}{l}\text {... takes into account cultural } \\
\text { customs and traditions of } \\
\text { Switzerland. }\end{array}$ & -0.02 & 0.67 & 0.39 & 0.11 \\
\hline
\end{tabular}

Note. The first 19 items (marked bold) were chosen for study 2. All factor loadings $\geq .33$ are marked bold. 
Table A3. Study 2: Principal Component Analysis of the 19 remaining items using Varimax with Kaiser Normalization as rotation method.

\begin{tabular}{|c|c|c|c|c|}
\hline $\begin{array}{l}\text { Item } \\
\text { The [organization XY] ... }\end{array}$ & political-social & moral-ethical & hedonistic-aestethical & utilitarian-instrumental \\
\hline $\begin{array}{l}\text {.. has a positive effect on social } \\
\text { relations in Switzerland. }\end{array}$ & 0.77 & 0.29 & 0.29 & 0.24 \\
\hline $\begin{array}{l}\ldots \text { creates a community in } \\
\text { Switzerland. }\end{array}$ & 0.76 & 0.31 & 0.31 & 0.19 \\
\hline $\begin{array}{l}\text {... contributes to social cohesion } \\
\text { in Switzerland. }\end{array}$ & 0.74 & 0.31 & 0.24 & 0.17 \\
\hline ... acts ethically correct. & 0.37 & 0.83 & 0.26 & 0.15 \\
\hline ... is fair. & 0.36 & 0.84 & 0.25 & 0.20 \\
\hline ... behaves decently. & 0.32 & 0.83 & 0.26 & 0.23 \\
\hline $\begin{array}{l}\ldots \text { is enjoyable for people in } \\
\text { Switzerland. }\end{array}$ & 0.29 & 0.21 & 0.74 & 0.24 \\
\hline $\begin{array}{l}\ldots \text { is pleasant for the } \\
\text { Swiss people. }\end{array}$ & 0.25 & 0.32 & 0.70 & 0.30 \\
\hline $\begin{array}{l}\text {... contributes to the quality of } \\
\text { life in Switzerland. }\end{array}$ & 0.21 & 0.28 & 0.70 & 0.25 \\
\hline $\begin{array}{l}\ldots \text { performs well in its } \\
\text { core business. }\end{array}$ & 0.21 & 0.21 & 0.33 & 0.68 \\
\hline $\begin{array}{l}\ldots \text { is professionally recognized in } \\
\text { Switzerland. }\end{array}$ & 0.16 & 0.18 & 0.22 & 0.83 \\
\hline$\ldots$ is economically viable. & 0.16 & 0.04 & 0.09 & 0.87 \\
\hline $\begin{array}{l}\text {... strengthens important social } \\
\text { groups in Switzerland. }\end{array}$ & 0.76 & 0.38 & 0.29 & 0.19 \\
\hline $\begin{array}{l}\text {... supports cooperation in } \\
\text { Switzerland. }\end{array}$ & 0.74 & 0.43 & 0.31 & 0.20 \\
\hline $\begin{array}{l}\ldots \text { helps to find social connections } \\
\text { in Switzerland. }\end{array}$ & 0.72 & 0.18 & 0.32 & 0.24 \\
\hline $\begin{array}{l}\text {... promotes well-being in } \\
\text { Switzerland. }\end{array}$ & 0.46 & 0.31 & 0.68 & 0.20 \\
\hline $\begin{array}{l}\ldots \text { contributes to the happiness of } \\
\text { the people in Switzerland. }\end{array}$ & 0.41 & 0.25 & 0.74 & 0.16 \\
\hline ... behaves kindly. & 0.37 & 0.82 & 0.27 & 0.18 \\
\hline $\begin{array}{l}\ldots \text { delivers high quality for the } \\
\text { Swiss society. }\end{array}$ & 0.25 & 0.22 & 0.40 & 0.73 \\
\hline
\end{tabular}

